\title{
Hukuk Felsefesi Konferansları
}

\author{
Yazan: Paul CUCHE \\ Grenoble Hukuk Fakültesinde \\ Profesör.
}

\author{
Çeviren: Hâmide TOPCYUOGLU \\ Hukuk Felsefesi ve Hukuk Sosyoloiisi \\ Asistan!
}

\section{ONSOZ}

Bu konferansların, hukukçulardan ve bilhassa hukukî tefekkürün yeni denemeleri hakkında bilgi edinmek isteyen felsefe öğrencilerinden mürekkep karısık bir dinleyici kitlesine karşı verildiğini hatırlatmayı zarurî görüyorum.

Bu konferansiar, Genel Ãmme Hukuku nazariyecilerinin uzun zamanlardan beri âşinâ oldukiarı bazı görüs tarzlarını, pek seçkin bir muhî̉ içinde basitleștirerek yayma yolunda bir teșebbüstür.

Bu ițibarla. bu görüş tarzlarını belki fazla mütebariz hatiarla tasvir edişim ve fazla müłekâsif bir şekilde ortaya koyusum mazur görülmelidir. Hukukî bir olgunluğa sahip olmamakla beraber, cidden en mücerret spkülasionlara dahi alıskın bazı aydınların bana ayırmıs oldukları konferans müddetım uzatmaya hakkim yoktu. Bana düşen herşeyden evvel, onları, açik ve kendi bilgi hazinelerine yerleșiirilmesi kolay ve düșündürücü sadelikleriyle bir teemmül tohumu olmaya elverişli bazı fikirlerle teçhizden ibaretti.

Konferansların metnini has isimler ve hașiyelerle doldurmayı lüzumsuz gördüm. Zaten malûmat sahibi dinleyicilerin ișine yaramıyacak olan bu tahșiyeler, bugün birbirleriyle çarpıșmakta olan hukukî doktrinlerle daha ilk defa temasa gelmek isteyen diğer dinleyiciler için de uygunsuz düșecekti.

Hülâsa maksadım, hukuk ilminin en yüksek problemlerine girişi kolaylaştırmak ve bunlarla alâkadar olabilecek kimselerin sayısını arttırmaktan ibaretti. Ne yazık ki, birçok hukukçuarın bu meselelerin cahili oldukları görölmektedir. Fakültelerimizin programları bu meselelerin tedkikini, bazan pek az talibi olan ve zaten her Fakültede okutulmayan doktora kurlarına 
bırakırlar. Acaba biraün, Hukukî Doktrinler Tarihine de, hic olmazsa Iktisadì Doktrinler Tarihi kadar bir yer verileceğini ümit edebilir miyiz? (1)

Tabii hukuk serabi

\section{(Le Mirage du Droit Naturel)}

Hukuk ilminin en yüksek problemlerinin uzun seneler zarfında fakültelerimizin programlarınđa yer futmadıkları söz göstermez bir hakikattir. Daha geçen asrın sonunda, saygı değer bir hukukcu olan Vareilles - Sommières eserlerinden birinin ön sözüne șöyle bașlıyordu.:

«Ben bu eserde bana hiçbir zaman öğretilmemiş olan şeyleri öğretiyorum: Hukukun ana prensiplerinis bundan sonra da, kendi zamaninda ve esasen cok daha évveldenberi fransız talebelerinin hukuk binasına, servis kapısına benzeyen bir yan kapıdan sokulmalarına ve uzun dehlizlerden dolaşırıldiktan sonra içinde enaz üç sene ikamef ettikleri bu muhteşem binanın heyeti umumiyesini biran bile göremeden yine ayni tarzda bir başka yan kapıdan çikarılmalarına teessüf eder.

Vareilles - Sommières'in ișaret ettiği bu vahim boşluğun bugün dahi doldurulmus olduğuna kani değilim. Hele hiç biri pek de eski olmayan bazi kitablarn ismilerine bakınca bu boșluğun yakın bir zamanda doldurulabileceğinden de süphe ediyorum: Amme hukukunun istihaleleri; Hususi hukukun istihaleleri, Hukukun tekâmülü ve maşeri viçan. Hukuk felsefesinde buhran.

Son zamanlarda hocalarınıdan biri hemen hemen ikiyüz sahifeye yakın bir eserinde hukukun bir tarifini araștırmağa kalkmamıs mı idi? (2)

Bütün bunlar hukuki düşünüşün bu anda Fransada bir kaynaşma safhasında olduğuna alâmet değil midir? Hukukun daha tarifi yapilamayan bir memlekette onun ana prensiplerinin öğretilmesini beklemek abestir.

Zahiren Code Napoléon'nun metafiziği ile tatmin edilmiş gibi görünen bu Fransız hukukçularının bir asra yakın bir zamanda hukukun menșe'i ve vazifesi hakkındaki yüksek nazariyata karșı hiç bir tecessüs duymamıs oldukları düşünülürse bu şimdiki kaynaşma ve tahammürün dahi başiı başına bir terakki teşkil ettiğine hüküm olunamaz mı?

(1) - Türk Hukuk Fakültelerinde bu ders 1933 vilindanberi Lisans programlan iiçinde ver almiștır. (Coviren I

(2) - Lévy-ULMANN : La Définition du Droit. Paris. Recueil Sirey. 1917 
Bu tavır değişmesinin asıl sebebini siz bilirsiniz.

Zamanımızı iktisadi zaruretlerini ve scsyal temennilerini artık hukusk alanındaki ferdiyetçilik düsturlarile tatmin etmek kabil olmuyordu.

Insanlar arasındaki karșılıklı tabiîyetin günden güna arttığı bir devirde, terdin «Bir havvanai bahçesinin kafesleri gibi etraflan çevrili hürriyel odacıkları içinde," (3) yaşadıklan faraziyesine dayanan bir hukuk nizamı ile ne yapilabilirdi?.

Bu itibarla hukukun görevi hakkında daha etraflı bir görüṣ tarzını aramak icap ediyordu.

Eu araştırmağa teșebbüs edenlerin hepsi ayni yoldan gitmedilersede hep si yine müșterek bir fikrin, müșterek bir endișesinin tesiri altinda idiler: Hukuku vakıalara yakiaştırmak fikri, tâki artık vakiaların kanuniara ısyanı gibi bir mesele bahis konusu olmasın.

Iște bu müşierek temayüle, münasip bulursaniz hukuki realizm temayülü deyelim. Ben bu tabiri șimdi muvakkaten kullanyorum Zira bu mefhumun ferifini asıl üçüncü konferarsımda yapmak niye indeyim.

Bu temayülden bir taraftan tabiî hukuk Rönesansı cereyanı, diğer tarafran de hukukî pozitivizm bas gösterir. Siz hepiniz, bu doktrin bașkalığı dolayısile birbirlerile çarpışan büyük hukukçuların adlarını bilirsiniz.

Köklü iearuzlanna rağmen tabii hukuk rönesansı cereyan! ile hukuki pozitivizm ayni zaviyeden tetkik edilebilirler. Her ikisi do hukuk ile inanç arasındaki münasebet meselesini ortaya koyar. Bunların, hukukî realizme doğru yoptklan hamlede Pozitivistler veya natüristler, inançan, yani vakıaların bosit bir müschedesinin bize telkin edemediği bazı deney-üstü (transcendental) methuniarın müdohalesinden kurtuimağa ne kadar muvaffak olabildiler? Een size her türlü hukuk telâkkisinin, hatrâ pek sarih bir șekilde pozitivist olanı bile, daima bir dini îmana veya hiç değilse bir metafizik postulatiar serisine inanmayı tazammun ettiğini isbat edeceğimi sanıyorum.

Fakat hukukî tefekkürün realizme doğru yaptı̆̆ bu gayrellerin, kendisinden ümił edilen hususiara ancak nâkıs bir surette cevap verebildiğine bakıpta, bütün hukukun uçsuz bucaksız bir mefhumculuktan, yani harici realitelere dayanmayan bir yığın mefhum Combinaisonlarından ibaret olduğu na hükmetmekten sakınmaiıdır. Hukukî gerçekcilik (Realizme juridique) ile hukukî mefhumculuk (Conceptualisme juridique) arasındaki mücadelede bahis konusu olanșey, bildiğiniz gibi, meșhur tüzel kișilik nazariyesidir.

(3! - R. Jhering - L'Évolution du Droit Sh: 335 
Esasen thevzzuv münhasiran tabî hukkuk ve hukuki pozitivizm otan bu dêrsi, tưzel kisilik nazariyesinin tetkiki ile bitirmekle dikkatinizi, bugün hokuk felsefesinin ortaya koyduğu en büyük Problemlerden üçü üzerine çekmiş òlacağımı ümit ederim.

Hukukî realizm temayülünün, neticede bir tabiî hukuk rönesansina varmasinda anlaştmayacak bir șey yoktur. Tabiata yaklaşmak, realiteye yaklașmak demek değil midir? Vakıalara uymak demek değimidir? Fakat burada da ince bir tefrik, bir katiyet icap etmez mi?

Bu tabiî hukuk rönesansi kareketinde, bu hukukun eski telâkki tarzı degiștirilmiștir. Tabiî hukuk artık bütün içtimaî münasebetler için gerekli prensipleri ve hal suretlerini ihtiva eden ideal bir hukuk gibi, mükemmel bir mevzuat sistemi gibi, bütün müsbet mevzuata örnek olacak bir șey gibi telakki edilmiyor. Tabiî hukuktan ancak bazi direktifler ve temenniler beklenebilceği hususunda herkes müttefiktir. Fakat bunlar müsbet hukukun hazırlanmasınà kanun koyan, yargıç veya hukuk bilgini gibi her hangi bir sıfatla iștirak edecek olanların hepsinin, dini veya felsefi kanaatları ne olursa olsun el birliğile kabul edebilecekleri direktifler ve temenniler olacaktır.

Işte bilhassa bu nokta üzerine dikkatinizi çekiyorum:

Bugün tabiî hukuk meselesinin ortaya çıkardığı münakașanın bülün amelî kiymeti buradadır. Tabiî hukuk rönesansî uğuruna sarf edilen gayretin gayesi; müsbet hukuku yaratmağa çalışan bütün bu gibi kimseler için üzerinde çalışabilecekleri müșterek bir anlașma zemini bulmak ve bunu tayin ve tahdit etmektir.

Kanun yapanlar, kanunu kendi keyflerine göre yapamazlar.

Bu kimseler kendilerine hakim olan bir takim direktiflere, yol göstremelere uymak zorundadırar. Zira uymak mecburiyetinde odukları bu prensipler bizzat eşya tabiatinden çıkmaktadırlar.

Kanuni şerh veya tatbik edenler ve çok defa onun boșluklarını ve belirsizliklerini izaleye çalıșanlar da yine ayni vecihle bu müşterek direktiflerden ve prensiplerden ilham almalidirlar.

Iște bugün tabiî hukuktan beklenen hizmetler bunlardır. Yalnız șimdi birşeyi bilmek kalıyor: Karşımızdakinin bir gerçeklik mi yoksa bir serab mr. olduğunu.

Pratik ehemmiyeti meydana çıkınca, yeniden meșhur tabiî hukuk meselesine dönmem gerekiyor. Şimdi ilk endișemiz, bu meseleyi eyi bir șekilde vaz etmek olmalidır. Bu hususta ayni mevzu hakkında şimdiye kadar müradele etmis olanlari adam akılı tenkıdde kendimi haklı buluyorum. Bunların hepsi esáslı bir tavzihi ihmal etmişlerdir. 
Kendisinden müșterek bir anlașma zemini yaratılması düșünülen bu tabii hukuk bir içtimaî hayat kaideleri serisimidir, yoksa bir ferdi imtiyazlar mecmuası midır? Bașka tabirle ve Duguit'nin bizi alıştırdığı bir terminoloji ile söyleyelim: Bu tabii hukuk, objektif bir hukuk mudur? yoksa sübjektif bir hak mi?

Tabiî hukuktan bahsedildiği zaman, sadece; bizzat beșer cemiyetlerinin mahiyeti icabı olan bir fakım sosyal hayat kaidelerinin mevcut olduğu mu söylenmek isteniyor, yoksa sadece bizzat beșer tabına merbut omaları dolayısile her ferde tanınması gereken bazı imtiyazların vücudundan mı bahsediliyor? Bu, halli gereken mühim bir nokładır. Bunu isbat için, Duguit nin içtimaî tesanüd kanunundan hareket ederek objektif bir tabiî hukukun vücudünü kabul ettiği halde şübjektif tabiî hakların varlığını șiddelle red ettiğini hazırlatmak kâfidir.

Daha baștan böyle bir tefrik yapmadan, tabiî hukuk münakaşasına girişmek imkânsızdır. Bununla beraber, meseleyi bu iki cepheden incelemeden evvel, gerek objektif tabiî hukuk taraftarlarının ve gerek sübjektif tabiî hokJar taraftarlarının ayni postulata dayandıkiarını işaret etmek lâzımdır.

Tabiî hukuk demek, tabiata uygun, tabiat tarafindan ilham ve emir olunan hukuk demektir. Yani insanın ferdi tabiatı tarafından yahut beşer cemiyetlerinin tabiaî̀ tarafindan ilham ve emir olunan hukuk.

Bu andan itibaren, tabiî hukukun bir müșterek direksiyonlar mihraki, bir müşterek anlașma zemini olabilmesi için-ki bu katiyen gözden kaçırılmamasi gereken bir noktadır-(tabiat) mefhumu üzerinde ve binnetice ister ferdlerin, ister beșer cemiyetlerinin menşei ve mukadderatı meseleleri üzerinde bir ittifak hasıl olmuș olması lâzımdır. Hülâsa; müsbet hukuku hazirlamağa uğraşanların hepsinin ayni içtimaî felsefede veya ayni insan felsefesinde birleşmiş olmaiarı lâzımdır.

Iște postulat budur.

Bunu tebarüz ettirmek için, söylemek kâfidir. Beyhude izahlara iüzum yok. Maamafi ben yine ısrar ediyorum, zira şimdi biz, objektif veya sübjektif olsun, bütün tabiî hukuk taraftarlarına karșı yapılabilen en ağır tenkidin karşısındayız. Evvelâ objektif tabii hukuk iddiasından bașlayalım. Acaba beșer cemiyetlerinin fonksiyonu ve gayesi hususunda ve içtimaî terakkiden ne murat edildiği bahsinde filozoflar, hukukçular ve siyaset adamları arasında, yakında, her hangi bir anlaşma meydana gelecek midir? Duguit'nin, bize içtimaî hayatın esas düsturu olarak kabul ettirmek için tesanüd kanununu ne kadar keyfî bir surette seçtiğine hayretteyim. Bundan kolayca - hattâ fikrim- 
ce pek fazla kolaylikla - çıardăı netice de bu tesanüdü arhran her seyin bir terakkî, azaltan her seyin de bir gerileme olduğudur.

Acaba müşahade mûtalârının bizi bŏyle bir neticeye sevk ettikleri doğru mudur?

Diğer filozof ve sosyologların, tabiatta müşahade ettikleri șeyin bilhassa zaiflerin kuvyetliler tarafından eziliși olduğunu ve tesanüd kanununu değil belki hayat mücadelesi kanununu gördüklerini ve bu kanunun da zihnî veya: maddi vasıfları ilerde irsiyetle intikal edecek olan en iyi ferderin seçilmesine ve güzidelerin yetişmesine yaradığını söylediklerini hiç ișitmedik mi?

Onlara göre terakki yolunu açan; tesanüd değil belki zorlamadir. Esas. itibarile biz, kendi dinî veya ahlakî nokłai nazarlarımızdan tecerrüde muvaffak olduğumuz takdirde sonunda onlara hak verecek değil miyiz?

Güzîdeler yetiștirmek, üstün ferdiyetler yaratmak, alelâdeler ve kifayetsizler sürüsünü çekip çevirecek, önüne katacak ve gayelerine ulaștiracak olan tam bir zekâya sahip müstesna şefler yaratmak, içtimaî terakkî yolunda, tesanüdü artırmağa nazaran daha emin bir surette yürümek demek değil midir? Tesanüdle beraber ferdlerin manevi kıymeti de artmazsa, bunun bize ne gibi bir âkibet hazırladığı endişesizce düșünülebilir mi?

Beser cemiyeterinin tabiatı ve gayesi hakkında bu kadar derin fikir tehalüfleri baki kaldıkça, objektif bir tabiî hukuk üzerinde ittifak edebilmek meselesi bahis mevzuu olamaz.

Sübjektif tabiî haklar münakașası ortaya çıktığı, ve bilhassa objektif: bukuka düșen rolü sadece bu ferdi hakların bir arada yaşayabilmelerini temine ve az evvel bahsettiğim faaliyet sahaları arasındaki eşitliği korumağa inhisar ettirmek iddiası ortaya atıldığı zaman, bizi, yine ayni netice beklemektedir. Halbuki iște bizim beșer haklan beyannamemize ve ihtilâlci ana yasalarımıza müessir olan ideoloii tamamen budur.

Insanın doğarken tabiatiyla bir takım haklara sahip olduğu nasıl izah. edilir? ve bu hakların ölçüsü nedir?

Bu suale nekadar muhtalif ve nekadar birbirile telifi imkânsız cevaplar verilir:

Bir kısmı bu tabii haklara mutlak bir mahiyet atfeder, onları beșer şahsındaki yüksek liyakatin izale olunamayan bir hassası gibi telâkki eder ki böylece hukukun insanda, yani hukuk nizamının meb'de ve gayesi demek olan insanda mündemiç olduğunu kabul mecburiyeti doğar. Bu, insanı yegâne mutlâk ölçü olarak kabul eden bir metafiziktir. Diğerleri ise bu ferdi 
thakları, ifâsına imkân verdikleri vazifelerle ve kendilerine irişilmesini mümkün kıldıkları bazı dünyeviliği aşan gayelerle izah ederler.

Bu takdirde bu haklarda mutlak olan hiç bir taraf yokiur. Zira bu hakIarın ölçüleri kendi varlik sebeperini teșkil eden vazife ve gayelerde mündemiçtir. Bazılanı ise kendilerini agnostique olarak tanıttıkları halde her ferdî hakda bir sosyal vazife mündemiç olduğunu ve «içimizden her birinin dünyada ancak sosyal hayatta ifa ettiği hizmet yüzünden bir varlık sebebine sahip olduğunu» söylerler. (4)

Hangi iolakkkiye iștirak edilirse edilsin, ferdi hakların ister muilaklı̆ı ister nisbiliğ iddia edilsin, bu neticelere müsahade veya tecrübe yolu ile varıidı̆ğn iddia efmek kabil değildir. Bu neticeler așikâr ve muhakkak bir surette bizim felsefi veya dini inancımızdan ileri gelmektedir. Demek ki, biz insan tabiatinden sadir olan ferdi haklardan bahsettiğimiz zaman, ancak kendi anladığımız manada bir insan tabiatinden bahseimekte olduğumuzu unutmamalıyı. Bu tasrihin șimdiye kadar daima ihmal edilmiş olmas: pek gariptir!.

Artk bu isballamayı uzałmak bana faydasız görünüyor ve meseleyi şu șekilde hülâsa ediyorum: Tabîi hukuktan, insanın veya cemiyetin tabiałı zannedilen şeyden sadır olan prensip ve direksiyonların heyeti mecmuası anlașıldğı. takelirde, müsbet hukuku hazırlayanlar arasında bu prensipler ve bu direksiyonlar üzerinde bir anlaşma tesisine muvaffak olmak imkânsızdır.

O halde yeniden doğan ve yenilermis olan tabii hukuk taraflarlarmm, sadece bütün itikad nevilerinin birbirile buluștuklan bir dörtyol as̆zmnda birleștiklerini ve ancak bu birleșme noktalarından ibaret olan bu daracik saha üzerinde çalısmakla iktifa ettiklerini kabul edebiliriz. Onlarn labii hukuk levhasın dikmek istedikleri zemin ne kadar dar olursa olsun ișłe bu zemindir.

Su halde, bu zeminin mevcut olup olmadiğı ve mevcut ise neleri ihtiva ettiğini sormak lâzımdir. Biz bu şekide anlassılan tabiî hukukun, artık hukukun tâli mahyietteki gayelerine (Les fins subalternes du Droit) irca edilmiş olacağını söylemekle her iki suale de ayni zamanda cevap vermis olacağız.

Her hal ve şartta, yani felsefí veya dinî istikametimiz ne olursa olsun, bizim hukuktan her zaman beklediğimiz bazı hizmetler vardır. Meselâ bizim hepimiz şahsımızın ve mallarımızın emniyet alıında bulunduğuna inanarak sulh içinde yaşamak isteriz.

(4) - Duguit - Transformation du Droit Prive 
Lçtimaî veya ferdi terakkiyi hangi cihetten ararsak arayalım, by terakkinin, insanların birbirlerini yemeleri halinde Boutroux'nun dediği gibi bir zorbalıklar hercümerci içinde ve ferdi öc-almalar arasında takip edilemiyeceği muhakkaktır. Sulh ve, emniyet, hukukun bize temin ile mükellef olduğy ilk nimetlerdir. Hukukun âli gayeleri hakkında giderilmesi imkârnsız derin bî́ anlaşmazlık halinde bulunsak bile, hukukun, bütün hepimizin ilgili bulunduğu bu orta derecedeki gayeleri tahakkuk ettirmesi gerektiği hususunda aramizda bir anlaşma yapabiliriz. Aż evvel söylediğim gibi hukukun menșe'i ve vazifesi hakkındaki bütün görüș tarzlarının birbirile karșılaștıklanı dörtyül ağzı iște tam burasıdır. Oyle hukukçu feylezoflar vardır $k i$ bu hududu hiç bir zaman așmamışlardır. Geny, haklı olarak Montesquieu'nun (Kanunlarin Ruhu) nda, Bentham'ın ise (Hukukî ve Cezai mevzuat) inde bu tâli derecedeki gayeleri takibi, hukuk nizamının bașlıca hedefi ad ettiklerine ișaret etmektedir.

Bu gayelerin sayısı çokłur ve insanların karşıliklı tobilyetlerinin her gün bir az daha fazlalaștığı bir cemiyetre bu sayının cittikçe artacağı da süphe götürmez. Sadece. nizam, emniyet ve içtimaî sulh icaplan bile, ferdlerin faaliyetleri için gittikçe daha büyük bir engel halini alan bir nizamlamayi gerektirmektedir. Bu tâli gayelerden ben yalnız ikisini, yani ehemmiyetleri iijbarile akla ilk gelenleri ele alıyorum; Sulh ve emniyet. Bunlarin daha baskalan da vardır. Meselâ Bentham (refah) dan da bahseder. Ben bu tabirin manasını daha genişleterek şöyle deyeceğim: Iktisadi hayatımızdaki istihar lelerin imkân ve icbarları nisbetinde hukukî münasebetlere daha fazla emniyet, daha fazla sürat ve daha fazla uygunluk sokabilecek olan herșey, hukukun tâli veya orta derecedeki gayeleri arasina gîrêr.

Hürriyet de hukukun orta derecedeki gayeleri arasına sokulabilir. Onun bir refah unsuru olduğy, ve hayatın hür bir memlekette, müsłebid bir iktidarm sopası alțnda yaşayan bir memlekete nazaran daha tath -olduğu aşikâr değil midir?

Fakat bu nokta üzerinde herkes hemfikir de olsa, hukukun bu hürriyet nimetini bize kaytsı ve tahditsiz alarak temin etmesi lấzımgelip gelmediği meselesi bahis mevzuu olunca derhal ayrlik bașlar, 0 nu insan tab'ının tefriki imkânsız bir hassası gibi, mutlâk seyler arasinda sayılan bir imtiyazı gibi telâkki edenler; onu bir gayeye erișme veya bìr vazifeyi ifor vasifası gibi telâkki edenlerle ayni kanaata sahip olamażlar. Bunları, sadece, tabit hukukun konakladiğı iddia edilen bu orta derecedeki gayeler zemininin pek nazik hudut meselelerini ortaya çıkardığını qästermek için söylüyoruz. 
Her ne olursa olsun, sabit olan birşey vardır ki o da, iman ve akide ihtilaflarna ve hukuku tarif hususunda her zaman hissedilmiş ve günümüzde dahi hissedilmekte olan güçlüklere rağmen, asırların cereyanı içinde hukukun muhakkak bir terakki kayıt etmiş olmasıdır. Bu tezad, hukukun bu terakkisinin hemen münhasıran kendi tâli gayelerine intibak hususundaki terakkisinden ibaret olduğunu kabul etmekten bașka ne ile izah edilebilir?

Fakat acaba bu intibaklar; tabiî hukukun bir sistemleștirilmesi sayesinde mi olmuștur? ve eğer istikbalde, sadece bu tâli ve orta derecedeki gayelerin bu orta - hattâ âdî - seviyesinde kalarak müsbet hukukun hazırianışın takipten başka birșey yapacak değilsek, bir tabiî hukuk rönesansı uğruna mücadeleye girismemize hakikaten ihtiyaç var mı? Bu kadar dar bir binaiçin bu kadar genis bir temele ne lüzum var? cemiyet halinde yaşanan her hayatın iptidai icapları tarafindan haitâ daha doğrusu herkesi kendi rahatını aramağa ve sahsını ve mallarını tehdit edebilecek tecavüzlere karşı korunmağa sevk eden nefsini koruma sevki tabiisi tarafından - ister istemez bize kabul ettirilen bir hukuk nizamıni, böyle büyük vaidlerin müjdecisi olan bir unvan ile süsemeye ne lüzum var?

Iște konferansımın birinci kısmında vardığım netice budur.

Yahutta tabiî hukuk taraftarları; hukuk hakkındaki kendi hususi görüslerini hukukun ôli gayeleri üzerinde dolaștırmak iddiasındadırlar ki bu takdirde bir tabii hukuktan bahsetmemek lâzımdır.: Zira hakikatia ne kadar içtimaî ve beșeri gaye tasarvuru mümkünse okadar da tabiî hukuk vardir.

Yahut da birbirine en muarı doktrinlerin hal suretleri, tabii hukuk namı altında foplanır. Bu zemin üzerinde kalmak demek, hukukun mense"ine ve en yüksek vazifesine doğru olan her terakkiden kendini alikoymak demektir. Bu, hukukî nizamda insiyakı mahiyette ve hemen hemen mantikla alâkası olmayan ne varsa, hepsinin önüne şatafatlı bir paravan koymak demektir.

Simdiye kadar, bir tabii hukuk serabından bahsetmekte haksız olduğumu zan etmiyorum. Biraz daha ilerliyelim, bu serabın biraz daha uzaklaștığını ve sonra büsbüfün gaip olduğunu göreceğiz.

Fiihakika tabii hukuk rönesansı cereyanı agnostique'lerde inkșiaf etmedi. Bu ihya teşebbüsüne çalışan hukukcular, kendi itikatlarından zerre kadar tecerrüd etmek lüzumuna kani değildirler. Bilhassa Geny. O, tarzı hareket kaidelerini tanzim ve bir action felsefesi ihzarı hususlarında agnosticisme'in aczini ısrarla söylüyordu. Ancak geneksel felsefedir ki beșer hayatının her şubesine sağlam bir temel hizmetini görebilir. (Geny - Science et 
technique II Sh, 359) Bu biraz mübhem olan tabirle Geny'nin Spritualist felsefeyi kast ettiŏine süphe yoktur. Baska yerlerde kullandı̆ı tabirle akliselim felsefesi yani ana hơflarile hôlâsa edímek icap ederse, kendisinin yarafitiŏt Käinattan ayr bir Allahın varligin, ruhun edebjyefini ve maneviyetini, insanu uhrevi akibatini kabul eden bir felsefe. Geny, hukukşu için bu felsefenîn neticelerine istinad elzemdir diyor. Fakat dahasi var: Müsbet hukukun yáraHlması için elzem olan araştımalar, sayet mefhumlar martıkınin sıki disiptininden baska hiçbri esase dayanmazsa, vakıalarin müsahade ve tahlilinden hiçbir faydah netice cikartilamaz. (Science ot Technique : H, n.9)

Burada sezgi ye, (intiutionl yani bu azhni sempaii ye ihtiyac varder. Bu ise ingncin tesiri altinda inkisaf eder. (Science et technique 1.80) Bu arada bir nokłaya isaret etmeme müsaade buyurulsun. Artik Ripertle beraber sunu sormaktan kendimi alamiyorum. :

* Su halde ne Tháiste ne de spritualist olan kimselere karși hangı deliller ileri sürülecektir? Bize yalnız sezginin ifșa ettiği ve başka hiç bir seye ircaı kabil olmayan bu tabii hukuks kabule onlar nasil zorlanabilirler?

(Droit nafurel ef positivisme iuridique. Annales de la Fácultê de Droit d'Aix. 1918. P. 23)

Fakat beni, yeniden yukarida söylediğim ve konferansimin ikinci kısmına dahil om hayán izahlara avdef etfirecek olan bu tenkidi uzatmayaym.

Simdi bu tabii hukukun ihyasına uğraşanlardan bir çoğunun manevî cephelerine temas edelim: Katolik itikadına mensup olduğum için sáhsen ben, Dualisto, theiste olan geleneksel felsefeye iltihakta hiçbir güçlük çekmiyorum. Yainiz müsbet hukukumuzun hazirlanmasi ve tefsiri hususlarında bu felsefenin bana ne gibi yardımlarda bulunacağını anlamak istiyorum Geny'in (Science ef technique en Droit privé) adlı büyük eseri bu hususta bize az sürprizler ifsa ermiyor. Zanmedersem en kuvvetlisi sudur: It ci cildde Geny, tabii hukukun yeni doktorlar arasında yöksek bir mevki isgal eden Alman cizviti P. Cathrein'in mühim bir eserini inceden inceye tahlile tabi . tutuyor. bo tahlilden bazı satırlan alıyorum. T. II. P. 374 * «abii hukuk ister Allahtan ister insanlardan sadır alsun, bilcümle mevzu emirlerin:müdahalesinden ât, ve bizzat tabiattan sadır olmalan dolayısiyle bütün beșeriyet hakkındar mecburt olan bir takım kaidelerin mecmuondan ibarettir ki sahalarmı chemmiyetle táhdidi gereken bu kaideter su iki düstura irca edilebilir. Herkese kendisine ait olani vermelisin. Kimseyi zarara sokmamailsın* Bu kadar mütevazi bir neticesi baskalanna kabul ettirebitmek için Cathrein'in mütaaddit defalar okuyucularına, kendi isbatlarının ancak açıkça «dualiște» ve «théiste» bir dưnya görūsūnụ kabul edẹnler hakkında bir katiyet ifade edeceğinj tak- 
rarlamasının faydadan halı olmadığını düşündüm. (Geny-Science et technique II. P. 318) Bu iki düstur, yukarda bahsi geçen hukukun orta derecedeki gayelerini aşmamaktadır. Ben burada herşeyden evvel insiyakın bir telkinini görüyorum ki bu, neden sonra hukukî bîr tefsíre mazhar olmuștur. fákat Cathrein'in eseri hakkındaki tahlili okumağa devam ederken aşă̆ıdaki iddiaya rastladığım zaman hayretim büsbütün arłıyor. :

¿Objektif manadaki bu tabii hukuk mefhumu, kendisinin bir müștakindan başka birșey olmayan tabii hak mefhumunu da belirtmeye kâfidir." ve işte mahirane bir el çabukluğu ile, bütün ferdî hakları, aile haklarını, mamelek hakların ihtiva eden bina, bu iki kaidenin daracık temeli üzerine kuruluverir. Itiraf edeyim ki bu yazı bende çocukca bir intiba bıraktı. Karşımda bir şapkanın içinden çeșit çeșit eşya çikaran hokkabazlardan biri var sandım. Çıkarılan şeylere hiçbirşey anlamadan bakdım durdum. "Herkese kendisine ait olan vermelisin» prensibi ile «kimseyi zarara sokmamalısin» prensibinden, hattâ kâinatın théiste ve dualiste bir telâkkisinin yardımile dahi insanın yașama hakkından, hürriyet hakkından ve vücuł bütünlüğünü muhafaza hakkından ve nihayet muayyen bir nisbette mülkiyet hakkından başka, diğer hususların nasıl çıkartılabileceğine hiç aklım ermiyordu.

Bu hakikati isbat için, tabii hukuk doktorları dediğim kimselerin en ciddi sosyal meselelerin halline mütaallik hususlardaki kifayetsizlikleri, aykırıları ve tereddütlerinden bașka delile ihtiyacım yok. Meselâ, bizotihi içtimaî bir unsur olan aileden bașlayalım;

Az evvel tarif ve tahdit edilen șekli ile objektif tabii hukukta hattâ geleneksel felsefenin yardımı ile dahi olsa, ailenin bünyesi hakkında esaslı işala, tabii hukuku ihlal etmiş olduğuna hüküm etmekte tereddüt etmiyecek midayanacaktır? Elinde bu bir çift düsturdan bașka birșey bulunmayan bir feylezof, bu suale ne cevap verecektir? Ve eğer yahudi veya hiristiyan ise, Allahın yahudi cịle babaları ve hükûmdarları için poligamiyi mübah kılmakla, tabii hukuku ihlal etmiş olduğuna hüküm etmekte teredaüit etmiyecek midir? Devam edelim: Bu monogamik veya poligamik aile acaba bozulması kabil bir evlenme ile mi yoksa bozulması imkânsız bir evlenme ile mi meydana gelecektir? Burada da tabii hukuk bize hiç bir cevap vermemektedir. Hiç değilse bizzat Geny'nin, evlenmenin bozulması caiz olmayıșının, tıpkı monagami gibi - hukukun (aklî mûłasi) tarafindan değil (ki bu aklî muta onun indinde tabii hukuka muadildir) belki «ideal» tarafından emir edildiği fikrinde olduğunu sanıyorum. (Science et technique II: 380, 402).

Devrimizin ana meselesi olan ișin teșkilâtlandırılması davasına gelelim. Bu hususta tabii hukukłan hangi direksiyonları elde edebiliriz? Evvelâ köle- 


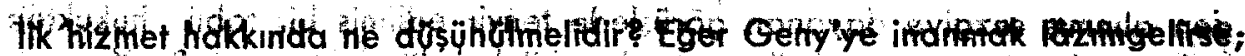

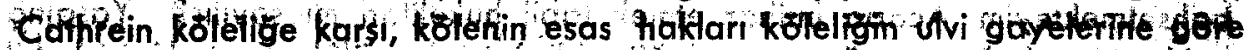

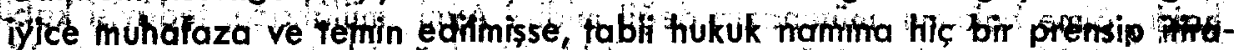

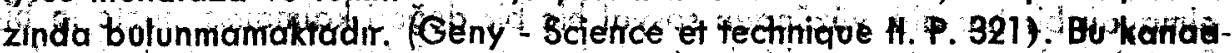

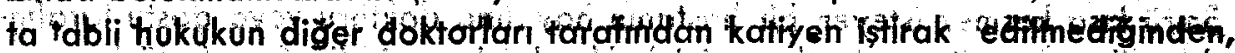

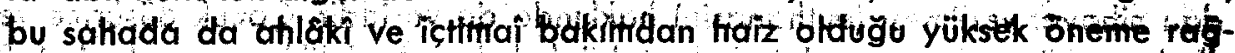
mén, hal soreti bulmadan birakinak zorưnda kalăğimı bir mesele tấh mevcuf otdugu neficesine variyorum.

Acaba tabii hukuk, is mukavelesine tanınması gereken hukukî mahiyet hakkında bize taha fazla bir șey mi zoğrettiyor. Onv bir kiratamia, bir satıs, yoksa bir şirket akdi mi ad etrneliyiz? Yine kesin bir cevap yok.

Bununla beraber sunu tasrih etmeliyim ki, tabii hukuk namuna kphusaplar, ecirlik rejimine karşı bir prensip itirazında bulunmamaktadirlar. Fakat adil ücret meselesi hakkınḍ, tıpkı adil fiyat meselesinde olduğu gibi araiarinda köklö ayrrliklar vạrdir.

Pẹk yakin zamanarda müsterek hayrn torifi, ve bilhassa onun ziddı olan ser mefhumunun tovzibi hususloranda tabii hukukun aczi sabit almgid mi? Buradin müstehcen nasxiyat karsi yapilan milleterarasi mücadelede bazl tcavruhareket kaideleri istihract igin iki defa girişilen gayretleri ima edjyorum. Muhakkak ki horseyden exval ise bir müstehcen tarifi ile haslangk lâzımdı. Bütün milletlerin müstehcenlik hakkında müsterek bị telakkkive sahip olmaları elzemdi, çünkü onun millelerarası bir surette önlenmesini temine calssiybrlardi. Hatblki ne niffefter cemiyetinin daveti özerine toplanan 1923

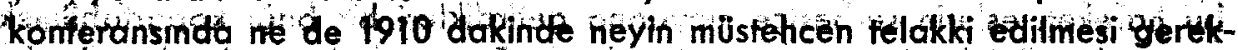
Hibi hususunda her hangi bir anlastmaya varilamad. Kendisine birinei dere-

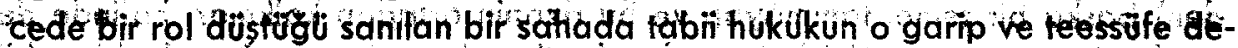
ger kifayetsiztlgit!

Listeyị uzatmak bence kolaydir. Tabii hưkukun, meselâ yasiyet yolu ile

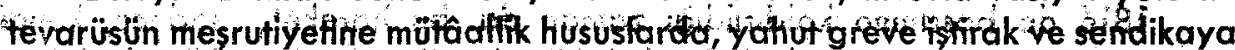
girme mecboriyetleri gibi bitbiritiden bir hayli fárkli mesefeterde daha sed-

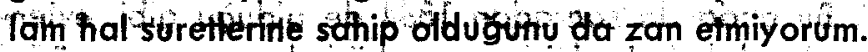

Tabij hukukun, müsbet hutukun hazrlanması için arz ædebileceŏi by yardimlar listesini sonuncu bir mesele ile yani bizzat kendi vücüdümüz uzerindeki hakkimiz (jus in se ipsun) meselesi ile kapatalım.

Bizzat kendi hayatımız, vücudumuzun bütünlüğü ve uzuvlarımızla bunlarin kûlanilmasi husúslarndádki fasarruf hưrriyêtimize, tabii hưkuk, hangi

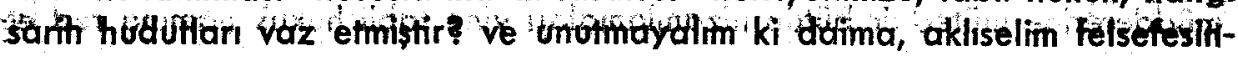


den alınmıs sezgiye dayanan görüşlerie tenvir edilmiş bir tabii hukuktan bahsetmekteyim. Acaba intihar etmek tabii hukuktan mı sayılır? Yașama hakkı, ölme hakkının mütenazın değil midir? Ayni mülâhaza, tedâvisi kabil olmayan bir hastalik yüzünden sosyal hiç bir değeri kalmamış muztarip bir ömrü kısa kesmek isteyen bir hastanın hayatına doktoru veya dostu tarafından nihayet verilmesi (euthanasie) hakkında da variddir. Cocuk düşürme ve ilkahsiz münasebet meselelerinde tabii hukukun kesinlikleri nerede kalır? iste bu da milletlerarası konferansların müstehceni tarif hususundaki aciz sebeplerinden birini teşkil eder.

Her ne zaman tabii hukuktan sarih direksiyonlar çıkartmak hayaline kapılınsa, bu direksiyonların, hakikatta daima zihnimizin bir itiyadi halini almıs olan dinî veya metafzik bir tarafgirliain telkinatından başka birsey olmadıkları görülür. Itiyad, ikinci bir tabiat demek olduğundan, bu karısłırmanin izahı basittir.

Keza, muayyen bir devirde ve muayyen bir cemiyette tabii görünen seyin, bir bașka zaman ve zemin sartları içinde itibardan düșmesi de yine aynı suretle izah edilebilir. Meşur muhtevası mütehavvil tabii hukuk nazariyesinin bu müșahadeden başka temeli yoktur. Hakikatta ise değișen şey insanın tabiatı değil, belki bizim, bu tabiatın menșe'i ve muakadderatı hakkındaki görüșümüzdür ve binnetice; halli gereken hukukî bir mesele hukukun tâli derecedeki gayelerini așhı̆ı zaman bizim bu görüșten tecerrüd etmemize imkân yoktur.

Medeni kanunlarımıza boşanma müesseseninin her iki sokuluşunda da, bu hareket, eşlerin serbestçe meydana getirdikleri bir bağı kopartabilmek husustaki tabii hakları namına yapılmıştı. Bu, vecibelere rizadan (iradeden) başka bir temel tanımayan ve bu rizanin ortadan kalkması halinde de vecibenin sona ereceğini kabul eden ferdiyetçi esaslara müstenid bir tabii haktı.

1816 da boșanma kaldırıldığı zaman da, bu hareket, sadece, kendi medeni müesseselerimizi devletin dini öğretimi ile ahenktar kılmak ihtiyacından doğma değildi. Bu anda da sonradan 1884 de olduğu gibi, evlenmenin bozulmaz birşey olarak kabul edilişi, yine tabii hukuk namına müdafaa edilmiști. Fakat artık bu tabii hukuk, ailenin istikrarını ve çocukların menfaatini, çok defa kurbanlardan birine isnadı kabil ferdi bahtsızlık mülâhazalarına üstün tutan «anti-individualiste» bir tabii hukuktu.

Liberaller tamamen başka bir fikir silsilesi içinde, büyüklerin günlük iş müddeterine mütedair bütün nizamlamaları yine tabii hukuk namına red et- 
mixorlar mi idis ve buno mukabil 1919 da kanun vazunnin múdahalesini tahrik eden husus da herkesirt ocak zevkine, ana babälik vazifelerini yaṕmagă, zihn̂̉ külfürônü gelistirmeye ve manevi olgunluğa erismeye müfaallik bir tabil hakka sahip oldưgu iddiasi değil mi idi?

Sunu da ilâve edeyim ki, hafta tatili usulü 1814 de konmus 1880 de kaldirılmıs ye 1906 da xeniden konmustur. Ve hic süphesiz bütün bu mütenakız kanunlar hep tabii hukuk namina yapılmıștir.

Burada da misaller listesi ilânihaye uzatilabilir. Iddiama messned olniàk için bana ikisi yefer. Boşanntadla bahis mevzuv olan şey, evtenmenin gaye-

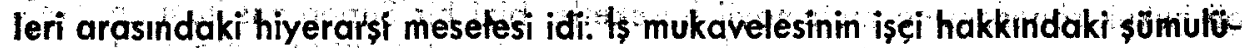
nü sekiz sad́fto tahdit eden kanunda bahis mevzuvo olán șey ise, mukaveleyi yapan insanio düfryevi ve uhrevi mukadderah idi. Her lk halde de tabioi hukuktan sarih hal suretteri çikartilabileceği zan edilmişti. Her ne hal ise vakiti su ki, müteaddit defálar, güdüklüğüne sahit olduğumuz bu hal suretlerinin, yine cülti akıl tạafindan tavsilye olunduğu ve mutlak bir klymèfe sahip bufundukIari iddia olunmuşfu.

Bu gibi yüksek meselelerin seviyesine cıkınca, tabii hukuk, artik swurlu veya suursuz bir îmanın telkini aldığından, bütün bu iman ihtilaflarının tepkisine maruz kaliyordu.

Hattâ bir zamahlar, herşeyin adalet mefhumư ile hal editebilecte tine

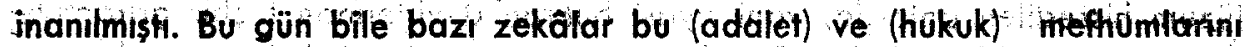
burlestirirler. Kanatimee bunda haksizdirlar. Zira bu mefhumlar birbitterine imibak éttirilemez. Fakat size bunu asbat ètmeye vaktim yok. Bo iki méthum ${ }^{2}$

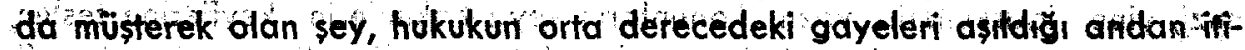
baren, her ikisinin de müsbet mevzuata sarih direksiyonlar vetebilimek hustsuridakíacizletidir.

Bir adaletin vücudu hakkinda bir hisse sahip olmak, sonra da neyin adil olduğunu doğru olarak bilememek. Iște adalet telâkkisini beșeriyetin mukadderat hakkındaki muayyen bir akideye rapt etmeyen insanin ebedi sskuntısı budur. Adaletin herseyin kendi gayesine intibak ettirimesi seklinde tarifi kabil olduŏundan ervelâ, daha mukaddem meselenin, yani gayeler meselesinin halli lốzımdir Bu yapılmadiŏı takdirde Geny nin yazdŏ gibi tek baspna mücerked adalet mefhumu, objektif hukukun ilmî bir surette ihzaruna hâfi bir temel teskil edebilmek bakımıdan, pek umumi, pek mübhen re pek vabanc hir mofhum olarak kajmaktadre (Science et technique II. P. 393). Bo-

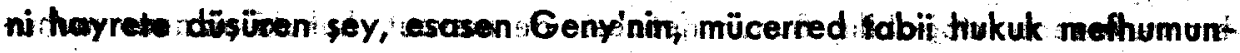
dan daha fazla bir yardım göreceğini sanmıs olmasıdır. 
Kendilerinde beşeriyẹtin hukukî servetini görmek arzusu ile, birkaç Dransip üzerinde birleșebilmek için sarf edilen bu azimli gayretlerin, cidden Dek müheyyiç bir manzara arz ettiğini itiraz ederim. Birbirlerile karșılaşmaları pek mutad olmayan Duguit ve Hauriou gịbi iłi zekâ tarafindan müdafaa edilen bugünkü (Superconstitutionnalité) anayasadan - üstünlük nazaryesi de böyle bir mülâhazadan doğmuș değil midir? Anayasadan üstün-

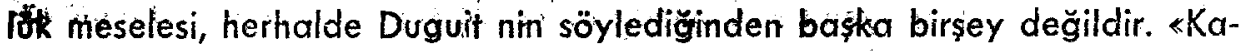
nun vazıının, haîtâ müessesan meclisinin dahi tecavüzlerinin fevkinde kalması cereken yazılı veya yazısız üstün bir hukuk». (Droit Constitutionnel 660). Tabi hukuka uyacak daha doğru bir tarifi beyhude aramıșım. Kanaatimce, tabü hukuk rönesansına mütemayil harekette, bizi bir Superconstituionnalité'yi tanımağa sevk eden hareket arasında ancak pek hafif bir görüs farkı vardrr. Bitincisi, üzerine bina kuracak toprak parçası bulmağa çalıșıyor. Ikinciși ise, bu toprak üzerine insa edilmis otan sey'i yıkılmaktan kurtarmağa uğtaşıyor. Buniar, sadece, bir hukukî katiyete, hukukî yakîne erişmek için yaprlan ayni faaliyetin, ayni hamlenin iki ayrı görünüsüdür. Bu faaliyet tarzı geçen asrın sonunda yaşayan hukukcuların zihinlerine aykırı düşer. Yani bu mevzuu hiç düsünmeyenlerin veya düșündüklerini zanneden bazı amatörlerin zihinlerine aykırı düşer. Bu manzaranın müheyyį̣ olduğunu söyletim. Fakat melankolik olmaktan hali olmadığını da kayt edeyim. Zira bu gayretlerin hiç biri muvaffak olmuşa benzememektedir. Prensipler halâ tavzhto muhtaçtır. Masuniyetlerine gelince; korkarım ki kendilerine en fazla lüzum hissedilen anlarda, yani siyasi buhran devirlerinde hiçbir garantiye mazhar değildirler. Netice: Suhalde ne zaman müsbet hukukun hazırlanmasi veya tatbiki, hukukun tâli derecẹdeki gayelerinin seviyesini aşarsa, kendimizi, yine idarecilerin, vazı kanunların veya hakimlerin keyflerine teslim don başka yapacak birşey kalmiyor demek? Bunar, kendi içtimaî ve felsefi telkinlerini, en müfrit neticelerine varıncaya kadar bize empoze edecekler öyle mi? Ben ihtilâl zamanları dıșinda; böyle bir ihtimalden korkulacağını zanetmiyorum. Bir cemiyet tabir caizse (sâkin) yaşadığı zaman, onu idare edenlerin yalnız âmme iktidarını elinde tutan ve bu sifatla hukukị kaideyi ihzar ve imal eden kimselerden ibaret olduğunu zan etmek Nipert'in dediği gibi, sathî bir görüștür. (P: 43) âmme kudretinin yanıbașındá ịktisadî, dinî kudret, matbuat ve umumi efkâr iktidari vardır. Iște bu kuvvêtlè hakimin veya kanun vázrinrti efinde nadiren birleşir ve çok defa birbirPerile ihtilaf halinde bulunurlar. Ontarı elinde futantar «Papazlar, ahlâkcılar, mülk sahipleri, Bankacılar, sendikalar, muharrirler, gazeteciler kendi Hêtülerini yürüfmek isteyen idarecilerdir. Bu nüfuz mücadelesinden tam bir muvazene doğabilir. Bunun neticesi de meveut hukukî nizamın muhafazasi olur.» 
Fakat bu müvazene tamamen elde edilmemis olsa dahi, bu nüfyzlarin

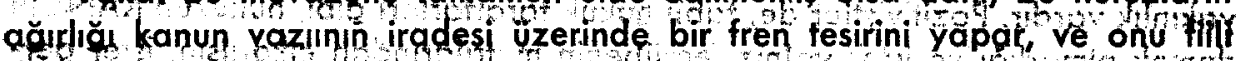
Whidgu pak fazla sikmaygcak olgn baz hal suretlerin kabule sevk edor. Mamafi bakimin hakimligin vexa kanun vazunin ifidalini biz sadece bir nu fuzlar ihtilafindan bekliyeçek değgiliz.

Biz, hiristiyanliklg muttgsif bir cemixette yasadığımızı bilmemezlikten athiyelim Isabetti bic mantusszth yüzünden hem bircok imansizlorin xicdanannda hemde bazl akidelerde hiristiyan ahlâk ve hukuk telâfkisi boki kolmina ve kilise ëgretimine dayanur) müsbat hukukun inzari icin; gelengksol felsefe veya akliselim felsefosine nisbetle cok daha sarih hal suretleri sodir olmaktadtr. Bïtür sübjektif haklarda, hattâ pek açk bir şekilde ferdí olanlarda bils mündemic olan bir içtimai vazife fikri, hakkın kötu kullonilmgs! nazariyesi, haksız iktisap mefhumunun genişletilmesi, büyük iş̧i ıslakgfı lfe kiz sagflik is güni ve pazar tatili gibil hasilı bütün bunların hepsi nihgi varIth sebeplerinin, en ince ve derin izahlarinı, hiristiyanlik tarafindan cizilmis beseri mukadderat plânenda bulur|ar. By plân, unumî hatlarile hầlầ kanun vgzil ve hakim üzarinde müessir olur xe onların kevfiliğini tadil eder.

Fakat bir itikadihi, nazarî akil sahasında gittikçe zevale yüz tutan tesirini ameli akıl sahası üzerinde ilânihaye uzatabileceğini de tahmin edémieyiz. Bu zeval tahakkuk edince, bu itikadın saliklerinin tabii hukuktan beyhude yere istimdad edeceklerini isbat ettiğimizi zan ederim. (5)

II

Hukukî Pozitivizmin Metafizik Postutatlari

(Les Postulats Mêtaphysiques dú Positivisme jưridique)

Hukukî pozitívizm, mösbeł hükukun tiazirlanthasin kanun koyenìn keyti iradesindeen kurtarmaya çalişan doktrinlerle akraba olur. Bu bakiından, huhuki pozitivizmle daha önce bahsettiğimiz tâbî hukuk rönesansı arasında bir

(5) - Bötün bu konferansta astâ akideler săhasinda deăil, belki vakıalar sahasm-

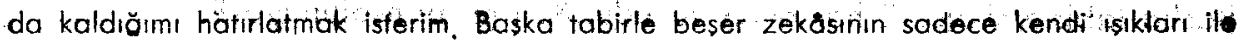
eifenin vexá cemivetin teakjlôtıng hokim olạn escasli orensipleti kesf edebilip odmiyeceăi meselesini münakaşa etmyiorum. Ben, kedilerinden faydalanılabilen ve itirazsizça ka. bul edilmis neticelerin bir blânçosunu yapmakla iktifa edivorum. Bu bakımdan täbit Hukuk naming konusan hukukcular arasındaki avkiriklan ve bunların icinde bocaladiklaf tereddüleri hesoba katmamak bence imkensizd. 
yakınlık vardır. Pozitivistler de, tabii hukuk taraftarları gibi, hukukun KANUN demek olmadığı ve ister yalnız tecrübenin mutalarından çikarılsın, ister gerçeklik üzerindeki müşahedenin muayyen bir kâinat ve beșerî mukadderat telâkkisine göre yapılmıs bir tefsirinden istihraç edilsin, dünyada, herhalde, tabii bir hukuk nizamı bulunduğu kanaatındadırlar.

Heriki zümre de, alman hukukcusu Seydel'in: «Hükümdarsız hukuk yoktur, Hükümdarın üstünde hukuk yoktur, Hükümdarla aynı sırada hukuk yoktưr, ancak Hükümdar sayesinde hukuk vardır. yolundaki meșhur düsiurune rêddetmekte birleşirler (SEYDEL-Grundzüge einer allgemeinen Staatslehre sh: 13,14$)$. Ben bu formülün; IHERING'in, hukukun kuvvetin yaptığı bir politika demek olduğu yani Kadiri-kül olan Devlet'in kendi kendisine vazettiği bir tahdit ve tayinden ibaret bulunduğu yolundaki șeklen daha yumușak fakat prensip itibariyle ayn derecede tehlikeli olan formülünden farklı telâkki edilmesine razı değilim.

Hayır; hukuk icad edilmez. Devletin bizi itaate mecbur ettiği harekeł kaideleri, sırf Devlet tarafından istenmis ve zorla kabul ettirilmiș olmalar yüzünden hukuk olmuş değillerdir. Oyle hususî düstur (norm) nevileri vardı" ki; bir yargıcın, bir kanunkoyanın veya alelâde bir şahsın hareketi, bu düs. turtara uyup uymamasına göre hukuka uygun veya hukuka aykırı telakkỉi edilir.

Bu esas tez olarak kabul edilince; bu düsturları (norm) bulmak için hangi metod takip edilmelidir?

Hukukî pozitivizmin en meșhur mümessili olan Duguit nin eseriadeki izahlara göre, ișie, hukukî pozitivizmin metodu şudur:

«Kanundan ve hukukun her fürlü şeklî kaynağından mukaddem olan bir hukuk var mıdır?» seklindeki sual ile ne kásd ediliyor.? Filhakika hukukî terminolojimizin kifayetsizliği yüzünden burada iki türlü tefsir kabildir.

Acaba cemiyetlerin muhafaza ve terakkîsi için elzem olan ve bu sebeple cemiyet halinde yaşayan insanlara zorla kabul ettirilmeleri gereken bit takım umumî içtimaî hayat kaideleri vardır mu demek isteniyor, başka tabirle, bir objekif hukuk vardir mı demek isteniyor,

Yoksa, her insanın şahsî imtiyazları mahiyetinde oian ve sırf insanlık sıfatı dolayısile sahip bulunduğu bir takım hakları vardır mı demek isłeniyor? Başka tabirie sübjektif haklar in vücudundan $m$ i bahsolunuyor?. tedir:

Böylece her iki tefsirle vaz edilen meseleye Duguit ș cevabı vermek-

«Ben, bütün dini, metafiziği araștırmalarıma karıșaktan uzaklaștırmak iddiasındayım. Sırf pozitivisł bir metod takip edebilmek için, ben, ancak müsahade ettiğim vakıalardan çıkan neticeyi doğru olarak kabul edebilirim. \$u 
halde evvelki mesele, «kanun koyanin liełkesce fáydalaniinıasi ve sayumasın garanti edeceği bir takim subbiaktif haklar Vofmidir; seklinde vaz edildiğ takdirde, buna yalniz mưssahede ve rectübe mûtalarindar çikan bir hak sure ti bulmak in̉kânsiz olự. Filhakika insánin dogarken bir takim hakłarf da beraber gefirdiğini hangl tecrübe veya müșahiadeye dayanarak söyleyebiliriz Böyle bir neticeye mesnet olarak gösterileçek vakıalar hangileridir?

Böyle hiç bir vakıa yoktur.

Burada, Duguit'nin muhakemesini tamamlamak, hattâ cüretim mazur görülsün, Islah etmek gerektiği kanaatindayım.

Duguit; mademki hakki istimal edenin iradesi, buna mutavaat edenin iradesine kendisini zorla kabul ettirmektedir, o halde her sübiektif hak bir ferdiciradeler hiyerarsisint tazammun eder diyor, Halbukj bu hixeicurs, ancak deney üstü (Trnscandental) methumlarłn müdahalesi scyesinde kurulabilir.

Bu itiraz pek muhtasardır. Sübjektif haklarin mevcudiyeti, bir iradeler hiyerarșisinden ziyade, bu iradelerin hizmet ettikleri bir menfactlar hiyerar-

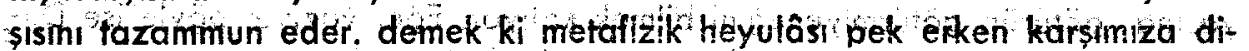
kilmektedir.

Fąkat ben bu iatısma üzerinde ssrar edecek değilim. Duguit nin esas itibariyle tamamen hakh oiduğu kanaatındaym. Sy muhakkaktırki sübiektif hakkar mevout olup olmadı̆ nu tayin meselesi, bizi derhal metafizik deryasina slïüklez.

Filhakika insan, bizzat kanunkoyanın bile kendilerine hürmetle mükellef olduğu bir takım haklara cicaba ne sıfafla sahip olacaktır?.

Bu suale iki ceyap verilebilir ki, bunların ikisi de tẹcrübedısı nevidendir.

Insan bu haklana ya ayüksek insanlik serefi» dalayısile sahiptị, yani surf ihsan olduğu için ki bu, hukukun insanda meknuz olduğu nazariyesini veya insana mutlak bir değer tanıyan metafiziği kabul demektir. Insan hukukun hem mebolei hem de gayesi olduğundan bütün bu imtiyazlar, mutlak, zevalsiz ve hudutsuzdurlar. Hudutl mademki insan bu ferdi haklari bizzat tabiatından almaktadir, o halde burada hududun ne iș var? Bu basma kalip fikirlerde, fransiz hukuk tefekkürünü yüz seneye yakın bir müddet beslemis olan ihtilâlei idéolojiyi bulursunuz!

Yahutta, insan, ifa edeceŏi bazı vazifeleri ve takip edeceği bazı gayeIeri alduğu için bir takım haklara sahiptir denecektir. Esasen bu iki fikir bir birile uyusur. Zira insan, gayelerine, bu vazifeleri yapmak suretile erecektir. Bu fordî haklar kendi ölçülerini, tıpkı her vasıtanın kendi ölçüsünü gayesinde buimasi gibi tekabüt ettikleri vazlfelerde bulurlar. Hirıstiyan hukuk nizamsnin aha haffarr iste bunlardir. 
Agnosticisme'e sığınılmadıkça, bu iki telâkkì, akla gelen yegâne cevaplarr teșkil eder. Insan kaderine mütaallik meselenin bir hal suretini ihliva etetmeleri dolayısile bu görüs tarzları, deney - üstü (Transcandental) mefhumlara bas vurmak zorundadirlar. Bütün gâi ve metafizik neviden araștırmalar, Lendilerine, tecrübenin mutalarında bir mesnet bulamazlar.

Iște şimdi Duguit nin hukuk meselesinin vaz'ında sübjektif görüşü neden dolayı katîyetle ret ettiği tamamen anlaşılıyor demektir.

Duguit ye göre, kanundan evvel ve kanundan üstün bir hukukun varlığı meselesi ancak bir tek mânâda anlașılabilir: objektif bir hukuk var mıdır? riayeti cebirle temin olunması gereken bazı içtimaî hayat kaideleri var mıdır? Hukukun ferdde meknuz olduğu nazariyesi ve ferde mutlak bir değer tanıyan metafizik yerine, hukukun cemiyette meknuz olduğu veya daha doğrusu cemiyetin hayatı ve terakkîsi için elzem olan bazı şartlarda mündemiç olduğu nazariyetini koyalım.

Simdi, bu ikinci meknuziyetin bizi birincisi gibi tam bir metafizik deryasıına götürüp götürmiyeceğini bilmek kalıyor. Eğer vaziyet böyle ise Duguit nin kabul ettiği hareket noktası esash faidesini gaip eder.

Halbuki hukukî pozitivizm şefinin bu meselenin ortaya atılacağını hiç tahmin efmediği görülüyor. Kendisi «hukuk meselesi bu objektif zaviyeden kolaylikla vaz'edilir» diyor. (Droit Constitutionnnel : tab : 2 cild: 1 sh II) sözün gelişinden anlașılacağı veçhile, mesele kolaylıkla vazedilebilir demek, Duguit'ye göre yalnız tecribenin mutalariyle hal edilebilecek șekilde vaz edilebilir demektir.

Düștüğü hataları yakalamak için Duguit'nin muhakemesini dikkatle takip edelim : bu konferans için, onun kendi metoduna karșı irtikâp ettiği sadakatsizliklerin birbiri arkasına incelenmesinden başka bir plân yapacak değilim.

«Insanın șuurlu ve içtimaî bir varlık olduğu, bir Postulał değil, belki doğrudan doğruya bir müşahade gibi kabùl edilmiștir. Bu sabit olduktan sonra cemiyet halinde yasayan insana kendini zorla kabul ettirecek olan bir kanunun zaruriliği derhal anlaşilır. Iște sırf bu yüzden insan cemiyetleri vardır ve yine sırf bu sebeple içtimaî bir kanun vardır. Insanın içtimaî bir mahlûk olduğunu, cemiyet içinde yaşadığını, ve cemiyetten başka bir yerde yașayamıyacağını kabul etmek, aynı zamanda, içtimaî bir kanunun vücudunu da kabul etmek demektir.x (Ayni eser sah: 12)

Itiraf edeyim ki tekrar tekrar okuduğum bu satı̣lar bende daima aynı derin hayreti uyandirmıştır. lç̣timaî mahiûklarin mevçut oluşundan, içtimât 


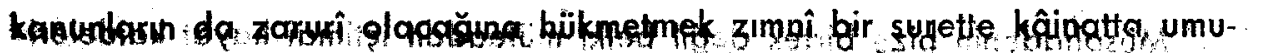

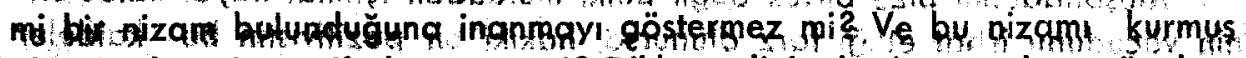
dan ifadaxe iment ifade etmgz mje Dikkat ediniz, bu iman yakıası tümden

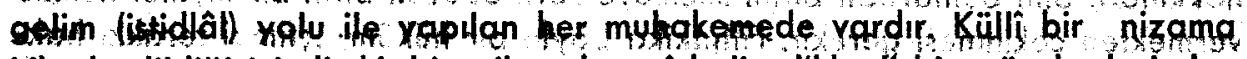

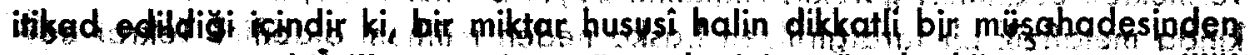
sanka, muayyen bir iltet - petice nüngsebetinin müstakarliă ve umumiliă

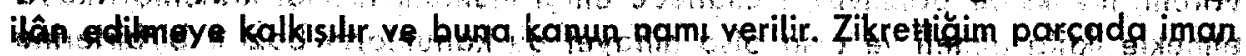
rajasi daha aqk bir sekilde tebarüz elmektedir : Mademki dünyada aemiyetler vardir, șu halde içtimaî kanunlar da var demektir! Müsahadesi kabil olan bütün hadiselerin bir kanuna tabi olduklarını ve ilerde de tabi kalacak-

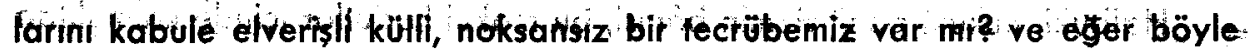
külî bir tecrübemiz yok da ancak kısmî tecrübelerimiz varsa, bunlardâhì bïzim kıyasımzdaki mukaddemleri aşan ve tecrübemizin bosluklannı dolduran: böyle bir neticeye qütürülmüs olmamız oncak deney - üstü (trapsegndantal); bir telkinin tesirile vaki olmus değil midit?

Bu muhakeme tarż, zaten; dostưth ve meslektasım le fur ün les L ettrës dergisindeki kHukukun Temelis adi makalesini okuduguum zamandamberi

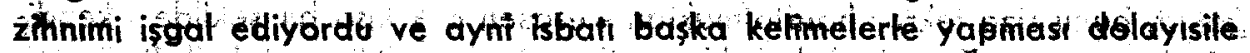

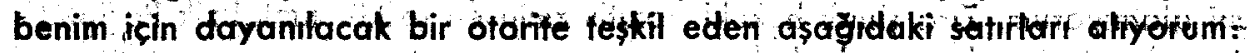
«müsbet ilimler sahasında kalmak isteyen altim, "tábîn kariuñ mefhừio ile intifo adebilir. Fakat pek asikârdur ki bu mefhum biraz tazyık edilirse bombos. alduğu ve har türlü manadan mahrum bulunduğu meydana çikar. Bunupla -ăer tabiatı̣ suurlu bir gayesi alduğu ve hakim bir iradeye sahip bulunduŏu iddia edilmek istenmiyorsa, bu tabir hic bir sey ifade etmez. Yani kendisine Hộu bir panô vercilmedikce hyndan birsey çkmaz. Müessir illet fikri olmakșzın ilim olamayacă̌ndan, insanun illetten illete intikgl ederek ta ilk illete. sebebi-ervele ( $k i$ bu her seyi izah eden birşey oldugundan ayni zamanda son sebepdir de) yani Allaha kadar varmasına hiç bir mâni yaktur. Demekki bu sözde tabii kanunlar için de, bütün diğer kanunlar için olduğu gibi, kendisini vaz'eden bir irade olmadikea kanun da olamaz düsturu caridir.y

Su halde her tünlü metgfiziğin gan düsngan olan Pyguit nin hykukî poitivizme temel elarak metafizik bir Postulat koymakla ise begladionı söylevebilitim.

Basks bir plânimı olmağğ̣ng göre tefkiklermize devam odelim:

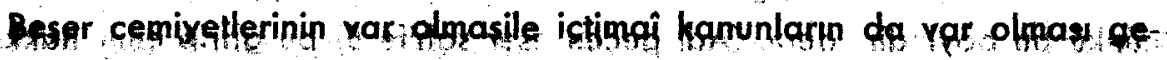

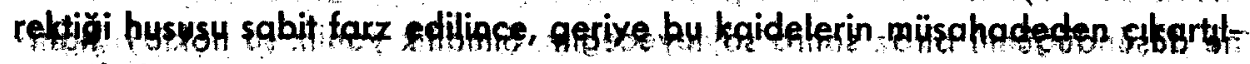
pont kalyy ar. 
Müșahadenin bize birtek değil belki müteaddit içtimaî hayat kaidelerinin vücudunu isbat ettiği farz olunursa, hakiki bir pozitivistin bu kaideler hakkında, onu bunlardan birini seçmeye sevk edecek olan bir kıymet hükmü vermekten çekinmesi gerekir. Filhakika böyle bir hüküm; içtimaî terakki hakkında metafizik bir tarafgirlikten bașka neden mülhem olabilir? Tekrar ediyorum, hakiki bir pozitivist, müșahede ettiği muhtelif içtimai kanunları kayd etmekle iktifa etmeli ve olsa olsa nihayet bu kanunların bazan birbirlerine zıd düșmeleri yüzünden birlikte tatbiklerinin imkânsız oluşuna teessüf ettiğini söylemeli.

Halbuki, hukukî pozitivizmin bânisi, bu makul hudutlar içinde kalmaktan uzakłır.

O, müşahadenin kendisine gösterdiği bu muhtelif içţimaî hayat kaidelerinden bir tanesini seçmiştir. Hakikatı söylemek lâzımgelirse, onun gözünde ancak bir tane içtimaî kanun vardir ve büłün diğerleri gölgede kalmıstır. O da, tesanüd veya karşılıklı tabiiyet kanunudur. Zaten son konferansımda, objektif tabiî hukuk meselesi münasebetile, bu usulün tenkidini yaptım. Fakat, bunu size tekrar hatırlatmakłan - esasen pek kısa bir sekilde - kendi. mi alamıyorum. Zira simdi hukuki pozitivizmin en aşikâr metafizik Postulat'. Jarından birinin karşısında bulunuyoruz.

Filhakika bu tarafgirlik niçin? Müşahade, tesanüd kadar mühim olan daha başka içtimaî kanunların da varlığını isbat etmiyor mu? Hepsinden evvel, en iyi evsaftaki ferdlerin istifasını intac eden ve tesanüd kanunu kadar terakkî tohumu tașıyan hayat mücadelesi kanunu yok mu? Medenî milletlerin sömürgelere yayılmasında ve doğum nisbeti az olan memleketleri istilô eden ve nüfuslarını karıştıran göçmen akınlarinida bu kanunun ceryanına sahit olmuyor muyuz?

Tesanüd kanunu, bu hayat mücadelesi kanununa niçin tercih edilsin? Hususîle, fercilerin manevi kıymetleri gittikçe azaldığından bunlar arasındaki karşılıklı tabiîyet artıșının kaygusuzca düşünülemiyeceği bir devirde?

Gayet iyi biliyorum ki, Duguit, bu hususta bir kıymet hükmü vermediğjni iddia edecek. Kendisinin (devlet, objektif hukuk ve müsbet kanun) adlı eserinden aşağıdaki satırları alıyorum «lçtimaî tesanüde dayanan hukuk kajdesi insana; şunu yap, çünkü bu senin hayrınadır, cünkü bu sana faidelidir, çünkü saadetin buna bağlıdır demez. O sadece bunu yap, çünkü bu vardır: çünkü bu böyledir: der». (Adı geçen eser sahife 6) bu garip emir hakkında ne düşündüğümü biraz sonra söyleyeceğim. Simdilik yanlız ș noktay hatırJahyorum. Duguit bizi bu tesanüd kanununa iştirake davet ediyor ve çünkü 
butesonüd konunu bir vakodir djyor. Fakat hoyat mücadelesi kanunu da bir vakıa değil mi? $O$ halde niçin biz obirine istirake zorlanyyoruz?

Mesele yine oldü̆ gibi kalıyor.

Biz daima fesanüd kanunu lehine olan tercihin ancak bir idealin aüf $x$ ve tesirile yapıldhŏını ve realitelerin basitbir müşahedesinin bize bunu telkindmüsait olmadigini zan elmekte hakiıyz:

with

Hülâsa, hukukị pozitivizmile bĭrlikte yürüdügưumüz yolun üzerinde iki metafizik Postulat'a carptikki bunlar olmasa idi aşağidaki hususlar tamamen anlaşimaz bir halde kalacaktı:

1 - Içtimoî norm ların vücudünü kabul etmek

2 - Objektif hukukun temeli olarak falan içtimaî normu tercih etmek:

Simdi nazariyeyi bıraktı̆̆rmiz yerden tetkike devam edelim :

Artık aşağıdaki mesele ile karșilaşmakłayız : Tesanüde istirak esasına. dayanan hukukî kaidenin icbar kuvvetini nasıl izah etmeli? Daha doğrusu bunu nasil haklı çkarmalı? Iste hukuki pozitivizmin en fazla hücuma maruz kaldığı nokta burasıdır. Baştanberi bu nazariyenin en zaif tarafi zaten burasi idi. Bu kalem mücadelesi baslayali onbes vildan fazla oluyor. Pozitivizm düsmanlarının en büyük gayreti tecrübe mûtâlarından bir emir istihracinın mümkün olamıyacağını isbata matuftu. Henri Poincarénin isabetli düsturunu kullanarak diyelimki, tecrübi hakikatlar daimầ ve ancạk ihbari (indicatif) mâhiyettedirler. (Dernieres Pensées: La morale et la science. Sh: 225) halbuki bir kıyasın mukaddemlerinin her ikiși de ihbari olunca, netice de bizzarure thbari olacaktır, Bu hususta hukuki pozitivizm aleyhine yöneltilen büłứn delîller böylece veciz bir şekilde hülâsa edilebilir. Bunu isbat için Duguit'nin en selâhiyet sahibi muarızları olan Michoud ve Geny den aldığım şu iki misál kêfidir:

Evvelâ Michoud'nun Bordeau Doyen'ine yazdiğı ve Duguit'nin (Hususi hukukun istihaleleri) adli kitabının ekinde pek dürüst bir hareketle neșrettiği bir mektuptan su parçayi alalım: «metafizik yapmaktan sizin dahi kurtulamadığınızı söylerken tecrübenin mûtaổlarını aștığı muhakkak olan hukuk kaidesi nozariyenizi ima ediyorum. Zira tecrübenin mûtâları bize yalnız tesanüd vakıasını gōsterirler fakat bundan doğrudan doğruya veya dolayısile cıkacak bir kaideye riayetle mükẹllef olduğumuzu hiç bir zaman isbat edemezler. Bu mükellefiyeti isbat için sadece bunun, insan topluluklarinm ve hatto bütün insaniyetin varluă ve refahi için zarurî olduğunu değil, ayni zamanda bizim bu varḷk ve refah uğruna calusmağa mecbur olduğumuzu da is- 
bat etmek lâzımdır. Deney - üstü (transcèndental) mefthumlara baș vurmadan hiç bu mümkün olur mu??»

(Hususî hukukta ilim ve teknik) adh büyük eserinde Geny de ayni itirazi yapar (Cilt : 2 sahife 263): knekadar mahirane bir tarzda ortaya konursa konsun, iddia edilen tesanüd ancak bir vakıadir. Binaenaleyh, bu vakıa söz götürmez bir tarzda kabu! edilmis olsa dahi yine, bu vakıanın, kendisini idame etmek ve artırmak mükellefiyetini meșru bir surette nasıl doğurduğunun da bize isbatı lâzımdır. Bos yere bize tesanüdün cemiyet hayatının esasłı bir şartı olduğu ve bu hayattan vaz geçemiyen insanın yine bizzat bu hayatın zoru ile tesanüdü tatbika sevk edildiği söylenip duruyor: Biz de daima nasıl olup da bu vakıa zaruriliğinin bir hukuk zaruriliği halini aldığını sorup duruyoruz.»

Duguit bu tenkitlere cevap verirken muarızları ile ayni saha içinde katmaktan daima kaçınmıştır. Hukukî kaidenin zorlayıcı kuvvetinden ne anlaşılması gerektiği hususunda muarızları ile hem fikir değildir. «Ben, insanlara kendini zorla kabul ettiren ve sosyal vakıaya dayanan bir norm'dan bahsettiğim zaman, bununla insanlara filen kendini kabul ettiren, onların varlıklarının mahiyetini, iradelerinin cevherìni hiç bir veçhile değiștirmeyen ve katiyen bir iradeler hyerarșisi kurmayan bir kaideyi istihdaf ediyorum.» (Droit Constitutionnel. Cild: I sh: 18) ve nihayet Duguit tesanüd kanununu cazibe kanununa benzetecek kadar ileri gidiyor: «Bir taş bir kulenin tepesinden asağı düșerken, onun mecburi olarak cisimlerin düșmesi kanununa iftiba ettiğini söylüyorum ve bunu söylerken deney üstü bir kaziyeyi beyan etmiyor belki farz ediyorum ve insanin sosyăl tâbiîyet kanununa mecburi olarak itaati gerektiğini söylediğim zaman da bundan daha fazla birșey yapıyor değilim.*

Sarahate olan düşkünlüğü ve mübhemiyete karşı olan nefretini pek iyi bildiğim Doyen'in böyle bir muhakeme ile kendini tatmin etmesine saşıyorum. Bunun, bize bahsettiği içtimaî kanun telâkkisi ile telifi imkânsız olduğunu ilk defa kendisinin fark etmesi lâzımdı. "lçtimẩ kanun bir illî kanun olamaz. Zira bu kanun insanların iradî ve șurlu hareketlerine tałbik edilir. Içtimaî kanun ancak gâi bị kanun olabilir, yani insanin șuurlu ve iradî faaliyetini sevk ve tahdit eden, insan arzusunun (iradesinin) mevzuunu ve thedefini tesbit eden bir kaide, bir düstur." bu ifade tarz mükemmeldir ve biz bunda mutabıkız. Fakat öyle ise düssen bir taş ile, tesanüd kanununa ifarait eden adam arasında niçln bir mümasefet görülüyor? Birinci halde ceryă eden bir illi kanundur, ikinci halde ise bir gâî kanun değil mi? Bu iki vażiyetin yalnız birbirine temsili değil birbirite mukayesesi bile mümkün de- 


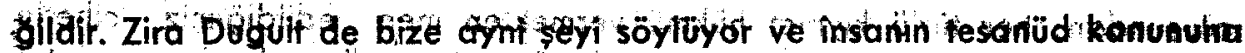

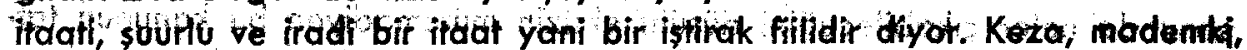
evvetce gordugomiz gibi-sosyal norm kiradenin cetheriti hiçbir vechile teoistirmemektedirs o haldè bi istirak fili de ithiyaridir.

Duguị̂ nin, metafizik hürriyể dediği cüz'î irade meselesi hakkınđa da her fóng bir farafo thihaktan sakindiğn thissediyorum. «Boyle bir hü riyet mercuf olabilir, fakat bunun hasselerimizle idraki mümkün değildins atiyor. bogưf ye gobre muhakkak olan sudur ki keger böyle bir fürrilyot meveotise, kanunun tatbikina rağmen yine olduğu gibi kalacakhır». (Droit Constituticahnel : I, 20) ayni vechile yine Duguit'ye göre suda muhakkaktır ki slnsan, sonunda kendi hareket tarzin tayin etmis olan hedefi, baștan seçip secmemekte muhtar bulunduğu kanaatındadır. Bunun bir hayaldan ibaret clmașnın ehemmiyeti yok. Vakıa şudur: dünyada, evvelce seçmiș olduğu guyeden bașka bir gayeys göre de hareket edébilmek ve evvelce yaptrğı bit jèden gayri bir seyi de yapabilmek kudretine sahip olduğunu his etmeyen tok bir bir insan yokłur." (Adr geçen eser: sah. 15)

Iște bir seri iddia ki (Traité de Droit Constutionnel) de yanyana dizilmis duruyor. Bunların birbirlerile tam bir vahdet teskil edip etmediklerini ye vo, meselâ herkeste, evvelce yaptığından baska türlü de hareket edébilmèk - kudretine sahip olduğu yolunda bir his bulunduğu kabul edildiği halde, hüfriyetin hasselermmizle anlaşılamıyacağın iddia etmenin doğru olup olmyyacağnı arashracak değilim. Hayır, büłün bu söylediklerimden yanlız sunu ele alıyorum: insan içtimai ve karşlıklı tabiyete iștirak ederken buna isstirak etmemenin de elinde olduğụnu bilmektedir, o halde niçin iștirak ediyor?

Bu suali, gerek kanun koyan, gerek yargic ve gerek her hangi bir tajzda hareket eden lâalettayin bir vătandas hakkında ortaya atıyorum.

Hukukî pozitivizmin birinci cevabı su olacaktır: Tesanüde iștirâk lâzımdir, çünkë tesanöd vakidir.» Archambault'nun (Ferdiyetçilik üzerine deneme) adti eserinde dediği gibi bu «biraz kaba ve esașen anlagrımasi imkânsız emirn i evvel münakașa etmistik, $O$ halde artık tesanüd, vâkî olan yegâne sey olmadığından Duguit'nin hukuk kaidesine temel olmak üzere onu tercih ediși, ancak, tecrübé - dișı névidén bir fèkinin fesiri ile izăh edilébilir.

Fakat șimdi münakașa bir bașka nokta üzerinde toplanmaktadır: Benim itiraz eftigim cihet, böyle ister fesanüd, ister hayat mücadelesi olsuh, her

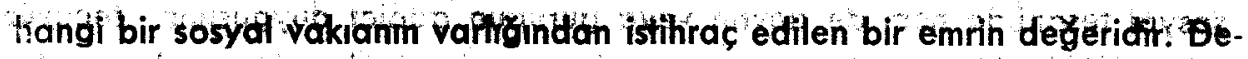
mek kibit seyin sadece mevcưt oluşu, bizim, o seyin vätuduhu idame ile pe arfirmakta müketlef olmamiz için kâfi sayhlyor. Bir sosyał kahunun heveot 
oluşundan; her türlü kıymet hükmü vermekten men edildiğimiz cihetle: sonunda neler çkabileceğini düșünmeksizin mütemadiyen bu kanunun tat-bik hallarıntçoğaltmakla mükellef oldugumuz neticesine varilyor. Bakınız böyle bir metodun meselâ Limitation kanunlarına tatbıkı ne manasız neticelere götürürdü..

Halbuki, bilâkis, insanın tabii, içtimaî veya biloloiik veya fiziki kanunları ögrenince sıf́ bunardan kaçma çarelerini aradığı da çok defa vâkî değil midir Hathâ hakîkî fikir adamlarının sözlerine bakılısa, terakki ișłe bundan ibarettir.

Hakikaten, «bunu yap, çünkü bu vakidir» yolunda bir vecize, bir baska gizli fikre mütenid olmadikça bir action felsefesine teklif ediiebilecek bir temel değildir.

Ben bu gizli fikri keșí ettiğimi sanyorum ve Duguit nin de bu fikri müsbet metoda yeni bir sadakatsizlik teskil etmeksizin münakaşaya sokabileceğini zannetmiyordum. Iste bir metafizik Postulas daha: eğer kbunu yapmak zımdır, çünkü bu vakidir» esosı doğru ise, insan, ferdi gayeler takip edemiyecek demektir. Bir uzviyef içerisindeki basit bir hücre gibi, ferd, cemiyein içine tıkılmı vaziyette ve işleyis tarzin ister istemez kabul ethiğ ve tenkid edemediği bir mekanizmaya istirak halinde kalacaktır. Duguit, (Hususi Hukukun istihaieieri) adi kitabında bugün ferdin içtimaî heyetten ibaref olan muazzam bir makinenin bir tekerleğinden bașka birșey oimadığ!n! ve içimizden her birmizin ancak sosyal yapida ifâ ettiği hizmê yüzünden bir hikmeti vücudu olduğunu pek açk bir șekilde biliyoruz, diyo: ladi geçen eser sh: 157) $8 u$ gibi iddialar münakaşa edilmez. Yalnız insanı hayrete düsürdüklerini söyleyeceğim, dogrusu pozitivizm ile mistisizm arasındaki uçurumun bu kadar dor olduğunu bilmiyordum:

Her halde, "bunu yap! çünü bu vakîdir" yolundaki vecizenin Duguit nin her zaman hoşuna gittiğini gördüm. Zira (Traité de Droit Constitutionnel) nin son tabinda hâlâ buna kıymet vermekte devam ediyor. Bu vecize eserin ilk sahifelerinde yer aimıştır. Bununla beraber, biraz ileride, hukukî norma has icbar edici kưveti izaha çalışırken artik bu vecizeye baş vurmuyor ladı geçen eser: sah. 63 ve devamı).

«Nezaman, diyor, bazı fiiller islense ve bunlar ferdî vicdana göre hem sosyal tesanüde hem de devrin veya gurubun adâlet duygusuna tecavüz gibi telâkki edilse, buniar, derhal hukukan mecburilik karakterini ihraz eden bir normun ihlâli gibi görülürler çünkü bütün herkes bu normun müeyyidesini 
fahakkuk ettirmek için teşkilâtlı hukuk yollarının derhal harekete geçmesini meşru ve zaruri sayar. Iște bu ve yalnız budur ki hukuk kaidesinin icbar kuvvetini teskil eder.»

Iște biraz ilerde daha açığı var: «eğer hukuk kaidesi ḅir icbar kuvvetine sahip ise, bu hal, ancak izah edilen mânâdadır., Yani kaidenin müeyyidelenmiş, sosyal cebrin harekete geçmesile garanti altına alınmıs olmasından ibarettir» (Sah : 71)

Böylece «bunu yap, çünkü bu vakîdir» vecizesi «bunu yapma, zira yaparsan içtimaî bir tarzda teșkilâtlanmış bir tepkiye maruz kalırsın” șeklindeki diğer bir vecize ile tamamlanmıs olur. Itiraf edeyim ki bu elverişli tamamlayicı unsur sayesinde hukuk kaidesinin icbar kurvetini daha iyi anliyorun: Hacizler, hapisler, mübașirler, jandarmalar.. beni itaata mecbur etmek için bu kadarı fazla zaten! Duguit içtimai kanuna tabiiyetin «iradenin cevherini bozmadığını, olduğu gibi bıraktığını» ve içtimaî cebir karșışında eğilmenin, norma, zatinde mündemiç bir icbar kuvveti tanımak demek olmadığını söylemekte elbette haklı idi.

Fakat artık mizaha sapıyoruz. Tereddütsüzce söyliyebilirim ki Duguit'nin hatası, kesin ve fazla umumi düșturlara olan zaf'ının hakikî fikrini gülünç bir kılığa sokmasındadır.

Muhakkakki basił bir yurtdaș için, hukuki kaideye icbar kuvveti bahș eden sey kendi vicdanının bu kaideye iltihakından ziyade, içtimaî cebir vakıasıdır.

Eğer mesele faideli bir tarzda vaz edilmek ve çocukca neticelere sürüklenmemek isteniyorsa, bu icbar kuvvetinin; kanunu koyan bakımından, ve daha umumi bir tarzda söylersek müsbet hukukun hazırlanmasına iștirak eden bütün diğer kimseler bakımından tetkik edilmesi lâzımdır. Kanun koyan, her hangi bir sosyal norma hukukî karakter tanımağa nasıl mecbur edilmiștir? Bașka tabirle, onu, bu norma itaat keyfiyetini içtimaî şekilde teşkilâtlanmıs bir cebirle teminat altına alma kararına sevk eden mucip sebepler nelerdir?

Görüyorsunuz ki böylece meseledeki had (terme) lerin yerini değiștiriyorum : Az evvel naklettiğim kısımdaki muhtevası ihtiyatsızca tesbit edilmiş olan formülün aksini alıyorum ve bu suretle meseleyi Duguit nin kasdettiği tarzda vaz edeceğimi sanıyorum. : «Eğer hukukî kaidenin bir icbar kuvveti varsa, bu, ihlâli halinde içtimaî cebrin harekete geçmesinden dolayıdır» cümlesi yerine, Duguit nin bunun tersini söylediŏini farz edelim : eğer içtimaî 
cebrin müdahalesi münasip görülüyorsa, bu, o iç̧imaî normda, onu hukukî kaideler sınıfına sokan icbar edici bir vasfın keșf edilmiş olmasından ötürüdür.

lyice anlaşılmışıłıki șayet pozitif metoda sadık kalınmak isteniyorsa bu icbar edici olmak vasfının bize deney-üstü (Transcendental) mefhumlar tarafından ilham edilmemiş olması lâzımdır: Metafiziğin içeri girmesi yasaktır! Bundan șu neticeye varmalıdır: mecburi olmak karakterinin kıstası kajdeye dıștan gelmelidir. Yoksa mecburiyet fikrini bizzat kaide tazammun etmemelidir. Aksi takdirde derhal metafiziğe sapmış oluruz.

Su halde bu kıstas nedir?

Ne zaman muayyen bir cemiyette insanların çoğunda, bir içtimaî kaideye hürmetin tesanüd ve adalet namına emir edildiği ve ihlâli halinin iç:maî şekilde teskilatlanmış bir müeyyideyi davet etmesi gerektiği hissi hası! olursa, iște o anda, o içtimaî norm, hukukî bir mahiyet kazanmıs olur. 'Şimdi artık kanun koyanın vazifesi bu normu derhal müsbet hukuk sahasına sokmaktır.

Bu arada, hukukî normun teşekkülü için içtimaîlik hissine ilâvesi istenecek olan adalet hissine karşı yapılan bu istimdada işaret edeyim. Bu adalet hissi, müsbet hukukun temelini genişletmek hususunda tesanüd hissi ile birleşecek olan yeni bir unsurdur. Mutad açıklı̣̆ı ile Duguit evvelki calıșmalarında bu hisse kâfi derecede ehemmiyet vermemiş olmasını haksız bulur. Simdi bu hisse kıymet vermektedir. Fakat bizi, onda bizatihi adil birșey görmekten sakınmağa davet eder, bizim bu adalet hissinde, belki alelâde bir adalet duygusu yani «insanların muayyen bir zamanda ve muayyen bir devirde haklı veya haksız hakkında icad ettikleri az çok mübhem bir mefhum» dan başka birşey görmememiz lâzımmış. (Adı geçen eser sahife : 50)

Içtimaîlik hissinde de daha fazla bir katîyet bulacağımızı ümit etmeyelim. Bizzat Duguit bize : tesanüd hakkında da ayni vecihle bir mefhumdan değil bir histen bahsetmiş olmasının sebebini kinsanların çoğu tarafından içtimaî tesanüd fikrinin iyice tarif edilemeyiși ve karanlık, yarı yarıya gayri meșur bir idrak olarak kalış» ile izah ediyor. (Adı geçen eser sahife 46)

Demekki böylece bir taraftan az çok mübhem bir mefhum o bir taraftan karanlık bir idrâk. Iște, hukukî pozitivizm, müsbet hukukun izharı için teklif ettiği kıstası böyle bir halıtadan imal ediyor! Eğer kanunkoyan bununla asł⿳⺈ tatmin edilemiyorsa, bunun cidden müsšül birșey olduğunu itiraf etmeli.

Burada hukukî pozitivizme karșı, evvelki konferansımda geleneksel felsefeye dayanan tabii hukuk taraftarları aleyhine sert ettiğim isbatlamay; 
tekrarlamak faydasız görünüyor. Orada aile teşkilâtı, meseki teșkilâtlanma, ve insanın kendi vücudu üzerindeki hakkının hudutları gibi, bir kelime ile müsbet hukukun ihzarı işinin ortaya çıkardığı en mühim problemler hakkında bu tabiî hukuktan sarih, söz götürmez direksiyonlar çıkarimanın imkânsız olduğunu söylemiştim. Adalet gibi karanlık bir idrakia birleşmiş tesanüd gibi mübhem bir mefhumdan da daha fazla yardım görülemiyeceği kanaatindeyim. Teklif edilen her hal sureti muayyen bir nisbette bu mübhem mefhumdan yardım isteyecektir ve neticede terazinin gözünü bir tarafa eğdirecek kuvvet, gayrimeşur bir metafizik tarafgirlik olacaktır.

Biz sadece iki misâl alalım. 27 Temmuz 1884 tarihli boșanmanın yeniden tecvizine mütedair kanun ile 5 Nisan 1910 tarihli köylü ve işçi tekaüdlük kanununu ele alalim:

1884 de boșanma lehine mücadele eden muharrir ve siyaset adamların!n bu ıslahatın içtimailik ve adalet hisleri tarafından emiredildiğine kani oldukları doğrumudur? Eğer hakikaten işe ferdiyetçi noktai nazardan bakarak muayyen bir adalet talebinde bulunmușlarsa, fikrimce burada aile teșkilâtını bozan bir ıslahat için içtimaîlik hissine istinad edebilmiş olmalarına hüküm etmek hayli güç olur. Her halde Duguit nin dediği gibi «hukuk kendi kuvvetini münhasıran ferdî vicdanların kendisine iltihakından alır.» (Adı geçen eser. Sahife 97). Burada 27 Temmuz 1884 kanununun bu kaidenin bir istisnasın teşkil ettiğini iddia etmek kabildir. Boșanmanın bizim medenî kanunumuza yeniden sokulmasının umumî efkârın baskısı tesirile olmadığı umumen kabul edilmiş bir vakıadır. Kitle bu meseleye lâkayıddı ve bu ıslahat lehine rey veren meclis çoğunluğu da bunu seçim vaidlerinin tazyiki alında yapmış değillerdi. Bu muhalif alâmetlere rağmen, bozulabilen evlenme prensibi hukuki kaideler arasına kolayca yerleşmiş, kanun bir öif yaratmış yahut daha doğ. rusu mevcuł örfü bozmuş ve boşanma müessesesi bizde adamakıllı kökleşmiştir.

Bilâkis șayet umumi efkârın uzun zamandánberi hazırlandığı teșriî bir yenilik varsa o da muhakkakki bu ișçi tekauddlüğü müessesesidir. Ferdî vicdanların iltihakı bu müessese lehine kazanılmışa juenziyordu ve diğer tarafran bu, içtimailik ve adalet hisleri tarafindan daha sarih bir şekilde talep edilmis bir islahattı. Bununla beraber 5 Nisan 1910 kanununun akbieti ve doğurduğu ümitlerle verdiği neticeler arasırdaki o acı nisbetsizlik de malûmumuzdur. Bu netice Duguit'nin düşündüğü gibi «mecburî tekaüdlük normunun henüz zihinlere yerleşmemiş olmasından» değildi. Bu sadece bir mükellefieyti henüz müeyyidesini teșkilâtlandırmadan ilân etmek gibi bir ihtiyatsızlık 
yüzündendi: Bu vaziyet karşısında bazı siyaset adamları tarafından desteklenmiş ve kendilerine bir iștirak külfeti tahmil etmeyen bir tekaüdlük müessesesinden faydalanacaklan hülyasile avutulmus olan ișçiler, onları iş birliğine davet eden kanuna karşı lâkayd kaldılar. Kanun koyan herşeyi tahmin ettiği halde, bizzat kendileri için kanun yapılan kimselerin buna lâkayd kalacaklarıı hesaba katmadığından, işçiler her türlü cebir vasıısının yokluğu sayesinde böylece ișe lâkayd kalabildiler. Garip şey, iște cebrin hukukî kaidenin icbar kuvvetini tamamlamak için münasip düsseceğ bir hal. Duguit bunun farkına varmısa benzemiyor ve 1910 kanunu misalini bundan başka çeșit ve tamamen tesirsiz bir delil istihracı için ileri sürüyor. Tam bir irtibatsızlık karșısındayız!

Müsbet hukukun hazırlanması için hukukî pozitivizmin içtimaîlik ve arialet hislerinden çıkartmak iddiasında bulunduğu bu kadar bulanık bir kıstastan hiç birşey beklenmemesi gerektiğini kâfi derecede isbat ettiğimi sanıyorum. Simdi işi rasyonel bir zaviyeden ele alarak böyle bir kıstasın pozitiv metodun icaplarile telifi imkânsız göründüğünü de ilâve edeyim. Tenkidin bütün şümulünü ihata için Duguit nin camiaların şahıslandırlıșının harikûlâde bir yıkıcısı olduğunu hatırlamak lâzımdırr. Zaten bu hususta onu cidden tebrik ederim. Milli ruh, mașeri irade, mașeri vicdan gibi sosyologların gözünde bir varlık ifade eden bütün bu mefhumlar onun nazarında yalnız «zihnin alelâde tasavvurları̀ indan ibarettir. (Sahife 59) Hakikatta ancak ferdî iradeler ve ferdî vicdanlar vardır. Fakat, hakikatta mevcut olsa idi muhakhakki ferdî benlikten üstün olacak ve hareket kạidelerine hukukî mahiyet bahs etmek kudretine sahip bulunacak olan bu mașeri benlik ve mașeri varlık putu bir kerre kırılınca, bizim ferdî vicdanlar otoritesi karşııında eğilmemiz icap ettiği ve hele bu vicdanların her hangi bir kaideye iltihak etmek ve ona bir icbar kurveti tanımak için birbirlerile kitle halinde birleșmeleri hususları nasıl anlașılabilir?.

Işe bir iradeler hiyerarşisi karışmadan bu nasıl anlaşılır? Halbuki biz zat Duguit bize her iradeler hiyerarşisinin metafizik bir telkini tazammun attiŏini söylemiștir. Kitlelerde, onları, cemiyetleri yaşatan şeylere doğru y:nelten ve cemiyetleri öIdüren şeylerden uzaklaștıran karanlık ve hattâ gayri meşur bir insiyak bulunduquna iman etmeden bu nasil anlaşilır? Keza burada da metafizik bir sahile yanassmıyormuyuz?

Bu tartışma üzerinde fazla durmaksızın, sözlerimi bitirirken şu «hukuk kuvvetini münhasıran ferdî vicdanların iltihakından alır» vecizesinin sonuncu bir neticesini daha hatırlatmak istiyorum ve bunu sadece hukuki pozitivizmin bunu tamamile kabul edip etmediğini araștırmak ve eğer kabul etmedi ise 
ondan ancak deney-üstü bir mefhumun yardımı ile kurtulabileceğini isbat etmek için yapıyorum. Böylece bütün metafizik Postulatları red ettiğini iddia eden bir doktrinin istinad ettiği metafizik Postulatların tetkikini bitirmiş olacağım.

Sayet hukuk, kuvvetini münhasıran ferdî vicdanların iltihakından alıyorsa. fikrimce bundan, kanun koyana düşen vazifenin, yavaş yavaş bu itlihakı elde etmiş olduğunu müșahade ettiği veya müșahede ettiğini zan ettiği bir takım hukuk kaidelerini kayd etmekten ibaret olduğu neticesi ;ikar. Bir kaide, bu gün mazhar olduğu ferdî vicdanlar iltihakından yarın mahrum kalabilir, bu iltihak kendisinden geri alnabilir. Bu zikzaklı harekete misal teșkil etmiyecek mevzuat varmıdır? Demekki bir milletin hukukunda bunlara ferdi vicdanların iltihakı ne kadar kuvvetli olursa olsun, her vaziî kanunu kendilerine hürmete mecbur eden yazılı veya yazısız bir takım prensipler bulunduğu fikri tecviz edilemez. Böylece hukukî pozitivizm bu iltihaktan zaman zaman istifade eden bu gibi kaideler hakkında hiç bir kıymet hükmü veremez. zaten bu kaidelerin ferdî vicdanların iltihakından kâh istifade edip kâh mahrum kalışları adalet ve içtimaîlik hislerindeki tahavvüllerin ifadesidir. Filhakikı her kıymet hükmü metafizik bir tarafkirlik istilzam eder. Demekki muhtevası son derece mutahavvil ve daima yenilenen bir hukukla iktifa etmemiz buna kanaat etmemiz lâzımdır.

Halbuki Duguit bu riza ve kanaata sahip olmaktan uzaktır ve biz kendisini bir kanundan üstünlük (Superléglité) hattâ bir anayasadan üstünlük (Supercenstitutionnalité) taraftarlarının en ileri gelenleri arasında sayabiliriz. O, alelâde kanundan üstün bir kanunda, yazılı veya yazısız olsun her halde hukukun bir âli prensibi bulunduğunu kabu eder (adı geçen eser 660 P. III) onun nazarinnda, hiç bir kanun koyanın, kıymetsiz ve icra kabiliyeti olmayan bir kanun yapmış olmak tehlikesini göze almadan kendilerini ihlâl edemiyeceği bir takım kaideler vardır. Bu kaideler bizim beșer hakları beyannamelerine mevdûdurlar ki, buna, sübjektif hakları inkâreden bir kimsenin garip bir kanaati demeden geçemiyoruz. Bunlar, ayni vechile, diyor, «bazı șartlar içinde milletin maşeri vicdani tarafindan telkin edilmişlerdir ki ben bu șartları kitabımın birinci cildinin birinci bölümünde mașerî vicdandaki içtimâilik ve adâlet hislerinin tepkilerini müşahede suretiyle tayine çalıştım.»

Iște muhakkakki bir kanundan üstünlük teșkil edebilmek bakımından hayli arizi ve mutahavvil unsurlar ve iște bizim beșer hakarı beyannameleri gibi hukuki ferdiyetçilik abidelerine karșı, içtimaî hukukun kurucusu tarafından gösterilen pek garip bir temayül. Şayet (hususî hukukun istiha- 
leleri) hakkındaki kiabında öğrettiği gibi bu ferdiyetçilik arłık devrini bitirmis se, neden dolayı ondan dokunulmaz prensipler çikartiliyor ve kanunların üstüne konuyor? ve şayet ben bu mantiksızlıklara, irtibatsızlıklara ișaret ediyorsam, bunu hiç bir zaman, cesur ve yüksek bir ilmî dürüstlüğe sahip bir zekânın tenakuzlarını yakalamak zevki için yapmıyorum, belki insanı bu gibi tenakuzlara düşüren şeyin sadece sistem kifayetsizliğinin doğrudan doğruya bir neticesi olduqunu göstermek için yapıyorum. Tecrübenin basit mûtâlarından «mut|âk»ı istihraç etmek mümkün değildir. Başka bir yerde «insan cemiyetlerinin muayyen bir gayeye doğru gitmekte olmaları mümkündür, ben bunu inkâr etmiyorum, fakat bu gayenin ne olduğunu bilmiyorum» dendiği halde, sonradan, gâi kanunlar olarak tavsif edilen bu gibi kanunlara bir takım dokunulmaz direksionlar izafe edilmesine imkân yokłur.

Hukukî Pozitivizmin böyle bir tezad içinde bocalaması, metafiziğ in bir intikamı olsa gerek!

\section{Hukukta Gerçekcilik ve Kavramallik Tüze! kișilik Kavramının Tenkidi \\ (Réalisme ef Conceptualisme juridiques.) \\ (Critique du Concep! de la Persornalité morale).}

Birinci konferansımın başında, hukuk ilminin bugünkü istikametini basif bir formül ile tarif etmek istediğim zaman, hukukì tefekküre hakim olan temayülün, hukuku vakıalara yaklaş̧ırmak olduğunu, yani gerçekçilik (Réalisme) temayülü olduğunu söylemiş ve bu tabirin yani hukukî gerçekçiliğin izahını ve neye tekabül ettiğinin araștırılmasını da sonuncu konușmamızdan beklemenizi rica etmiștim.

Hukuku vakıalara yaklaștırmak, evvelce gördüğümüz gibi, hukuku vakıalardan istihraç etmek demek değildir. Hukukî pozitivizmin bu teşebbüste muvaffak olmadığını ve hukukun gaiyyeti meselesinin metafiziğin yardımı olmaksızın hal edilemiyeceğini size isbat ettiğimi zan ederim: Pozitivizmin bu hezimetini, hukukî gerçekcilik hesabına kayd etmek büyük bir hata olur. Gerçekcilik temayülü ile metafizik arasında hiçbir nevi uyuşmazlık mevcut değildir.

O halde hukukî gerçekçilik nedir? Bu, sadece, hukuku hayata intibak ettirmekten, hukukî inşalar arasında dolașırken bunların karșılamaları gereken pratik ihtiyaçları gözden kaçırmamakłan ve müesseselerimize kendi sosyal ve ekonomik hayatımızdaki istihalelerin gerektirdiği elastikiyeti ver- 
mekten mi ibarettir? Eğer böyle ise, evli kadının evlilik birliğini temsil selâhiyeti, is kazalarında mesleki riziko mefhumu, hakkın kötüye kullanılması nazariyesi, ev ișlerinde çalışan ışçilere asgarî bir gündelik verilmesi usulü gib̆i hususlar hep hukukî gerçekciliğin birer zaferi sayılacaktır.

Bu, geçekçiliğin pek fazla mübhem bir telâkkisi olurdu. Bu telakki, gerçek çiliğe karșı çıkarılması mutad olan ve mefhumculuk (kavramcilik - Coceptualisme) denen temayül ile gerçekçilik arasındaki ziddiyetleri tamamen ifadeye kâfi gelmezdi.

Zannımca, gerçekçiliği kavramcilıktan Realisme'i, *Conceptualisme* den ayırt eden șey, gerçekçilikten ne anlașılması gerektiği meselesidir. Hukukî inşaların gerçeğe dayanmaları, gerçekten hareket etmeleri lüzumunu takdir hususunda herkes müttefiktir, Gerçek nedir? Bu kelime hukuk ilminde hususî bir maana mi ifáde ediyor? Ediyorsa bu mana nedir?

Doğrudan doğruya bu suale bir cevap bulmağa çalşmak iyi bir usul olmıyacaktır. Evvelâ biz bu suálin hangi şartlar içinde soruduğunu tetkik edelim, bu şartlar bize sualin hakikî șümulünü aydınlatacaktır.

Fransada gerçekçilik - mefhumculuk (Conceptualișme) - (Réalisme) münakaşası Duguit ile Saleilles arasında bașladı. Mefhumculuk daha başka müdafiler de bulduğu için bu münakaşa Saleilles'in ölümünden sonra da devam etti. Münakaşa üç mefhum etrafında dönmekłe idi: hukuk süjesi mefhumu, sübjektif hak mefhumu, ve tüzel kişilik mefhumu.

Duguit için sübjektif hak, metafizik bir faraziyeden başka birșey değildir. Dolayısile hukuk süjesi mefhumu da bir sübjektif hak sahibini ifade için kullanılmaz. Bu mefhum ancak «objektif hukuk kaidelerine tabi olan mahlûk» u ifade edebilir (Droit Constituonnel I. Sh: 319). Tüzel kişilik mefhumuna gelince; bunu tamamen bırakmak lâzımdır. Zira bir taraftan sübjektif hakların sahibi sıfatile tüzel kișinin artık hikmeti vücudu kalmaz. Diğer taraftan ancak șuurlu bir irade ile mücehhez olan münferit insandır ki objektif hukukun süjesi olabilir.

Duguit bu tasfiyeyi daha doğrusu hukukî mefhumlar dünyasındaki bu esaslı kadroların ilgasını nasıl haklı gösteriyor, nasıl izah edebiliyor? «ben maddi dünyada olduğu gibi sosyal dünyada da ancak vasıtasız müşahade yolu ile tesbit ettiğim șeyleri gerçek olarak kabul ederim ve bu suretle tesbit ettiğim bütün șeyleri de gerçek sayarım. Müșahadesi kaḅil olmayan șeyler gerçek değildir ve müşahadesi kabil bütün şeyler de gerçektir. Iște her ilmin vaz geçilmesi imkânsız postulat'ı budur. Fakat bundan daha ileriye gitmemek lâzımdır." Halbuki Duguit şunu da ilave etmektedir. (Artık nakil değil hü- 
lâse ediyorum): «Bununla beraber, ihlâlleri bir tepkiyi davet eden bir takım içtimai kaidelerin vücudunu görüyorum. Insan bu kaidelere itaat ettiği müddetçe objektif hukukun süjesidir. Iște bütün gördüklerim bunlardan ibarettir. Müşahade bana hiçbir zaman bir müstefidi veya tâbii bulunan bir sübjektif hakkın varlığını tesbite imkân vermedi. Bu, bir mefhumdan başka birsey değildir. Yine pek haklı olarak ferdlerde her hangi bir hukuki șahsiyetin mevcudiyetini de müşahade yolu ile tesbit etmis değilim. Topluluklarda, teşekküllerde ve müesseselerde yine hiç bir zaman bunu tesbit edemedim. Bu da yine bir mefhumdan ibarettir."

Demek ki, müsbet hukukun, münhasıran müşahadesi kabil gerçekliklere dayanmak suretile değil de, bu mefhumlar üzerinde oynanmak ve bunlardan muhtelif terkipler yapılmak suretile hazırlanacağını iddia edenlerin hepsi mefhumcudur.

Ezcümle Saleilles'in tüzel kișilik hakkındaki kiłabında buna verdiği cevabı, kendisine yapılan hücuma iyice uydurabilmek için yine nakil değil șerh ediyorum: gerçeklikler çeșit çeșittir. Hukukî gerçeklikler, tabii veya maddi gerçeklikler ile karıștırılmamalıdır. Bunların hepsi, içlerinde kavramsal (mefhumî - Concepłuelle) bir unsur taşımakla diğer gerçekliklerden ayrulırlar. Hukukî gerçekliğin en mutlak olanı, en cezrîsi bile bu mefhumî unsura müracaata mecburdur. Demek ki $\circ$ da bizzarure bir mefhumculukfur. Su halde harici bir seniyetin yanında mefhumî bir unsuru da ihtiva etmeleri yüzünden sübiektif hak veya tüzel kişilik gibi mefhumların hukukî gerçeklik sıfatı inkâr edilmemelidir. «Bir mefhum, ancak tamamile gerçeklikten kurtarıldığı ve bizzat mahiyeti dolayısile hayattan kati surette tecrid edilmiş bir mantık aleti muamelesi gördüğü takdirdedir ki sırf bir hukuk tekniği unsuru haline irca edilmis olur. Fakat yine bu hali ile de biz onun faydalı olduğunu ve hakların kendi gayelerine mükemmel bir şekilde intibak etmelerine yardım ettiğini görürsek, mefhumculuk ile ittiham edilmek tehlikesinden korkmadan pekâla bu mefhumu kullanmakta tereddüt etmeyiz."

Iște birbirlerine karșı vaziyet almıs hasımların durumları. Her nekadar münakaşa daha az karanlık bir hale gelmis isede, ben henüz kâfi derecede aydınlanmıs olmadığını, haklı olarak, kayit ediyorum. Şimdi bu. telâkkiler arasında nekadar ziddiyet varsa hepsini daha açık bir şekilde tebarüz ettirecek misaller alacağım :

Fakat herşeyden evvel kelimelere kapılmayalım. Her ilmin mefhumlar üzerine kurulduğunu unułmayalım. Bir fizik kanunu bir mefhumdur, keza bir geometri teoremi de bir mefhumdur. lște bir kâat parçasi üzerine çizilmiş 
bir üç̆gn. Bunun yanı bașına tıpkı ona benzeyen veya eșit olan diğer bir üçgeni de ben çiziyorum. Simdi derhal bu iki şekil arasında, birinci üçgeni hiçbir veçhile değiștirmeyen bir münasebet, bir eșitlik veya benzeklik münasebeti ortaya çıkıor. Bu münasebet, bir münasebet olarak bizim zihnimizin yarattiğı bir şeydir, bir mefhumdur. Demek ki hukuk ilminin de geniș bir mefhumculuktan ibaret olmasına șaşmayalım. Her ilim esas itibarile eşyanın birbirilerile olan münasebetleri hakkında bir bilgidir. Illiyet münasebeti, müsabehet münasebeti, teaküp ve terafuk münasebeti, gîiyyet münasebeti vesaire gibi. Halbuki bu münasebetler mefhumlardan ibarettir.

Şimdi burada kötü manada değil de hakîki manasile mefhumculuk kelimesi kullanilırsa, en inadeı realistler bile sadece objektif hukuka dayanan bir hukuk sisłeminin mefhumculuk teșkil etmek bakımından, sübjektif hukuk esasına dayanan bir hukuk sisteminden hiç de geri kalmadığını bilmemezlikten gelemezler.

Artık sübjektif hukukun bir mefhum olduğu malîmmdur. Bu, ister yalnız ferdler arasında ister ferdlerle eşya arasında olsun, her iki haldede iki şey arasında kurulmuş bir münasebet demektir. $\mathrm{O}$ halde bir mefhumdur.

Fakat münhasıran objektif temele dayanan hukuk da ayni veçhile yine bir münasebet değil midir? Iște, hukukî nizamın temeli ve sosyal hayat kaidesi olarak teklif edilen tesanüd veya karșlıkh tabiiyet kaideleri.. Ferdlerin faaliyetleri ancak bu kaideye uygun olarak icra edildiği takdirde cebir vasıtasile himayeye lâyık olacaktır. Fakat Duguit nin tabirile «sübjektif bir hukukî cuiuum» içinde bulunan ferde tanınacak olan tu sosyal himayeyi bulup çıkarma melekesi bir mefhum değilde nedir? Esasen tesanüd ve karșılıklı tâbiiyet gibi șeyler birer münasebeti ifade ettiklerine göre bunlar da birer mefhum değil midir?

Evet amma deyecekler, bunlar müșahedesi kabil realiteden istihraç edilmiş mefhumlardır, bunların kabulï ve kullanılmaları ile gerçeklik sahasından dışarı çıkılmış olmaz. Fakat sözde mefhumcular da sübjektif hukuku müdafaa ettikleri zaman yine bu gerçeklik sahasından daha fazla dışarı çkıyor değillerdi: lki ferd bir mukavele yapar, bu mukavelenin neticesinde içlerinden biri herhangi bir edanın alacaklısı, diğeri ise borçlusu olur. Tediye yapılmadığı takdirde alacaklı içtimai cebre müracaat eder. Borçlusuna kar\$ł kanuni cebri icra yollarını kullanır. Bu cebre müracaat selâhiyeti ise az çok müşahedesi kabil bir keyfiyettir ve neticeleri de görülüp hissedilebilir șeylerdir. Biz ișłe bu selâhiyete sübjektif hak diyoruz. Siz ise bunu sübjektif 
hukuki durum adı ile ifadeyi tercih ediyorsunuz. Simdilik bu noktayı münakaşa dışı bırakalımda, ne siz ne de biz gerçeklik sahasından dışarı çıkmayalım.

Sübjektif hak mefhumu, diyorsunuz, öyle bir iradeler hiyerarşisini isiilzam ediyorki, melafiziğe olan nefretimizden dolayı biz bu hiyerarşiyi șiddetle red ediyoruz. Fakat bu iradeler hiyerarşisini icad eden sizsiniz. Mukavelelere riayet, münasebetlerde emniyet sosyal hayatın iptidai ihtiyaçlarındandir ve bu haller hukukun, pozitivist veya metafizikçi olsun bütün hukukçulara kendilerini zorla kabul ettiren tali veya mutavassit gayerindendir. \$ste mukavelelerin icbar kuvvetinin bu sebepten dolayı içtimai cebirle müeyyidelenmesi gerekir ve bütün alacaklılarin sahip oldukları bu cebre müraacat selâhiyetine biz sübjektif hak adını verdiğimiz zaman, bu tabirin delalet ettiği şey artık bir iradeler hiyerarșisi değil, belki bir menfaatlar hiyerarşisidir. Biz, mukavelenin ifasını isteyen alacaklının menfaatinin, mukaveleden kurtulmak isteyen borçlu menfaatine tercihi gerektiği fikrindeyiz.

Bu menfaatler hiyerarssisini biz, aynen, sizin, sübjektif hukuk mefhumu yerine ikame ettiğiniz «sübjektif hukukî durum» mefhumunda da müşahade ediyoruz. Bu duruma sahip olanın bu duruma hak iddia edenin menfaati, bu durumu tanımamağa çalışanın menfaatine tercih edilmelidir., Zira birinin iradesi tesanüd kanununa uymakładır; diğerinin iradesi ise bu kanuna aykırı hareket etmektedir. Görüyorsunuzki bu isbat tarzını biraz daha ileri götürürsek sizi de bir iradeler hiyerarşisi kabul etmekle ittihama kadar varacă̆ız.

Bu bizanskâri münakaşayı burada durdurmakla arzularınızı yerine getireceğimi sanıyorum. Sübjektif hukukun müşahadesi kabil bir gerçeklik üzerine kurulmus olduğunu isbat için zaten münakaşayı hayli uzattım. Bu mefhumun icine muhakkakki bir mefhumu unsur giriyor: lki ferd arasinda mukavele vasitasile kurulan münasebet. Fakat ayni zamanda gözle görülen ve elle tutulan diğer bir methum da giriyor: Bu münasebetin müeyyidesi olan icrai takip yolu. Bu iki unsur okadar sıkı bir șekilde birbirile birleşmekte ve mefhumî unsur olan sübjektif hak, müşahade edilebilen unsur olan (dava) dan okadar tabii bir șekilde istihraç edilmektedir ki Edit'leri șerh eden hukukşinaslar tarafindan pretör hukukunun ayni suretle sistemleștirilmesi buna bir misal teșkil eder.

Oyle sanıyorumki Duguit hücum nokłasını iyi seçmedi. Kötü manaya alınan, yani hayattan tecrid edilmis ve gerçeklikle tamamen alâkası kesilmis olan bir takım hukuki inşalar mecmuası manasına gelen mefhumculuk ile 
böyle bir saha üzerinde mücadeleye girişmekte haksızdı. Adam akıllı ve samîmî bir şekilde realist olmakla beraber sübjektif hak mefhumuna yine sadık kalınabilir. Realistler tarafindan ortaya atılan münakaşa artık sübjektif hak mefhumunu değil, ancak, mahz (pur) hukuk tekniği mefhumlarını bahịs konusu ettiği zaman bir mana kazanabilir.

Hukuk tekniği mi? Iște yine tarifi gereken bir mefhum, belki de beni, daha mefhumculuk meselesini bitirmeden önünüze bu kadar belirsiz diğer bir mefhum cıkarmıs olmakla ittiham edeceksiniz. Fakat bu ittiham yersiz olacaktır. Zira ben ayni zamanda iki kitabı birden okuyor değilim ve sizi realistlerin anladığı manadaki mefhumculuğun ne olduğunu cincak teknik mefhumunu incelemek suretile anlayabileceğinize ikna edeceğimi ümit ediyorum.

Sizleri, teknik hakkında, yani hukuk vokabülerinde de ilk göründüğü andanberi thering tarafindan kuvvetle iltizam edilen bu tabir hakkında șimdiye kada teklif edilmiş olan çeșitli tarifler içinde bunaltacak değilim. Eldeki lûgatlara bakınca, tekniğin, bir sanatta, bir meslekte veya bir imalatta: kullanılan usullerin heyefi mecmuası demek olduğu görülür.

Su halde evvelâ prensipler vardır sonra da bu prensipleri ameli sahaya naketmeye ve onların muayyen bir bakımdan en müesssir en basit ve en elverișli tatbik suretlerini bulmağa yarayan bir teknik vardır.

Oyle zan ederimki umumi olarak bu fazla karmaşık olmayan Techique mefhumu, bize, hukuk tekniyi hakkında bir fikir vermeye kâfi gelecektir. Fakat bunu size isbat etmeden evvel ve daha dogrusu bunu size daha açık bir şekilde izah için size hakikatta bir çok hukuk teknikleri bulunduğunu göstermenin faydalı oldungunu sanıyorum. Evvlâ bir yasama tekniyi (teșri teknivi) vardır. Sonra da kanunu șerh veya tatbikle mükellef olanların kullandıkları bir teknik vardır. Doktrin ve ictihad tekniği. Teșri veya yasama tekniği; kanun yajpanların, hukuka düșen vazife hakkındaki kendi görüşlerine göre arzuya değer saydıkları bazı gayelere erişmelerine imkân verecek usulleri seçmeleri demektir.

En basit bir misal alalım :

Insanın melekeleri ancak tedrici bir șekilde inkişaf ettiğinden, bir insanın hukukî ehliyetini ölçmek için yaşının nazara alınması tabiidir. Umumi fikir işto budur.

Simdi bu fikrin teșri tekniği vasıtasile nasıl kuvveden file çıkarıldığına bakalım: Evvelâ, hangi yaştan itibaren ferdin tam bir ehliyete sahip ad edileceğini tesbit etmek lâzımair. Bu rüșad yașının anane, ırk, aile öfü nazara: 
alınarak tesbiti de bir teknik ișidir. Bu, isabet derecesi tecrübe edilecek ve belkide bizde olduğu gibi evlenme rüsșü bakımından tadile tabi tutulacak bir rakamdir.

Suhalde henüz bu yaşa geimemiş olan bir insana ne muamele yapılacaktır? Küçük, tamamen ehliyetsiz olacak ve mamelekinin idaresi bakımından zarurî veya sadece faydalı olan bazı hukukî muameleleri yapmak selâhiyeti reșit büyüklere mi verilecektir? Yahutta bu muamelelerden her hangi birini yapmak gerektiği takdirde küçük serbest bırakılmakla beraber kendisine reșid büyüklerin yardımı temin edilmekle mi iktifa olunacaktır? "Negotorum gestio» mu, yoksa «Auctoritatis interpositio» mu? Yani, selâhiyeti olmadan bașkası hesabına tasarruf kaideleri mi, yoksa velâyet veya vesayetin müdahalesi mi, hangisi?

Roma hukuku her iki usulü birden kullanmışı. Bizim medeni kanunumuz bunlardan ancak birini kabul eder. İste bir teknik meselesi.

Ayni vecihle, muamelelerin mefruz ehemmiyetine göre himaye șiddeti aźalıp çoğalacak olan bir vesayet müessesesinin teșkilâtlandırılması da bir teknik ișidir. Keza, adi rüșd yașını beklemenin pek fazla gecikmeyi mucip telâkki edildiqi bazı istisna: hallerdeki kazi rüșị müessesesi de bir teknik işidir.

Misaller sayısızdır ve fazlasını vermekłen vaz geçiyorum. Zira doğrusunu söylemek lâzımgelirse kanun koyanın vazifesi zaten bu teknik iși yapmaktan ibarettir. Bir kanunun prensipler vaz etmekle işe bașladığı nadiren vakidir. Vaktiyle bizim medeni kanunumuzun bașında sonradan ihzârî çalışmalar sırasında kaldırlmış olan bir (ilkbab) bulunduğu ve bunun da bir (prensipler babı) olduğunu hatırlatmak lâzım mı? (6) Çok defa teşrii çalışma, ihtimalki gerekçede ifade edilmis ve fakat kanun maddelerinde tekrarlanmamıs olan falan veya filan içtimai telakkiyi filiyat sahasına geçirmeye yarayacak vasıtaları araştırmak ve düzenlemekten ibarettir: Kanun maddeleri yalnız Jhering'in tekniğin gayesini tarif için kullanıldığı isabetli tabiri ile bu içtimai fikrin (tatbik kabiliyeti) ni organize ederer. Bu tatbik imkânını elde etmek için çok defa kanun koyanın bir Fiksion veya bir karine gibi bazı suni vasıtaları kullandığı vakidir. misalları bunların zikrini faydasız kılacak kadar çoktur. Maamafi ben bu sun'î vasıtaların muhakkak ki en fazla istimal edilenini katiyen meskût geçmek istemezdim. Yani «herkesin kanunu bildiğini ve kimsenin onun tatbıkından kurtulmak için kendi cehaletini ileri

(6) - Bak: Bizde mecellenin ilk vüz maddesi. (ceviren) 
sürmiyeceğini kabul etmekten veya kabul eder görünmekten» ibaret olan fiksiyonu (Fiction).

Doktrin ve ictihad teknikleri de bu teşri tekniğine dayanırlar. Bunlardan biri, kanun koyanın eserini sistemleștirmeyi, tarihleri ve mevzuları farklı olan kanunî nizamlamalar arasındaki mütaaddit yakınlıklan bulup çıkarmağı, hukukî tasnıfler veya kałegoriler icad etmeyi kendisinin yeğane değilsede başlıca gayesi olarak kabul eder. Digeri de kanun koyanın eserini temamlamağı kendisinin yegâne değilsede başlıca gayesi olarak kabul eder, zira kanun koyan herșeyi baștan derpiş etmemiștir, halbuki ceza hukuku sahası hariç, diger bütün sahalarda, kanun koyan derpiş etmiş olsun olmasın, mahkemeye gelen her husus hakkında bir hüküm verilebilmesi lazımdır.

İște bu suretledirki metinler kıyas yolu ile genișletilerek tatbik edilir, bazi Fiction'lar veya karineler istimal edilir. Mesela karının ev masrafları hususunda kocayi zımni temsili gibi. Keza tesanüdün günden güne artığı bir cemiyette büyük sayıdaki zarar vakialarının tamiri için kusura dayanan mesuliyet yerine, file dayanan mesuliyeti ikame maksadile risk mefhumunun genişletilmesi gibi.

Bu teşri, ictihad veya doktrin teknikleri, gaiyet fikrinden, yani irişilecek bir hedef düşüncesinden mülhem olmaktan hali kalmadıkça, mefhumculuk itabi ile haksız olarak karșılașırlar.

Meselâ tevarüsün tanzimi usullerini kolaylaștırmak ve mirascılara rücu davalarını önlemek için bizim medeni kanunumuza izalei şuyuun neticesi (Partage déclaratif) gibi bir mefhumu sokmus olmasından dolayı kanun koyandan sikâyet edilebilir mi? Bonu yapmakla hayatın icaplarına cevap vermiş değil midir? Réaliłleri hiç göz önüne amladan mı bunu yapmıștır.?

Keza, az evvel ișaret ettiğim içtihad tarafından yapılmış inșalar (Construction'lar) hakkında da ayni şey söylenebilir. Onlar da pratik zaruretlerin tazyiki altında yapılmamıs mıdır? Fakat bazan teknik faaliyet hayattan tecerrüd eder ve artık gerçekliğe dayanmaz. Bazi hallerde teknik unsurlara tatbık edilen hukuki muhakeme; her çeşit gaiyet fikrine kapılarını kapamis olan bir mahz mantık havası içinde mücerred bir şekilde gelişir, tayin ve işaret olunan olaylar üzerindeki muhakeme yerine, bu yapma işaretler üzerindeki muhakeme kaim olur, artık teknik unsurlar cebir işaretleri gibi istimal ve,terkip edilirler. 
Iște böyle anlarda, teknisiyenler, hukukî inşaların (Construction) yegâne hikmeti vücutları olan esas gayeyi gözden kaçırırlarsa, kötü maanadaki mefhumculuk tehlikesine maruz kalırlar.

Burada da misaller eksik değildir. Meselâ rast gele birini alalım: Yani haciz vaz ettiren alacaklılarla, mahcuz alacağı temellük etmiş olan kimsenin birleșmeleri halini tanzim için teklif edilen kombinezonları hatırlayalım. Ya hut da ceza hukukunda cezayi hafifleten sebeplerle, tekerrür yüzünden ağırlaștıran sebeplerin birleșmesi halini alalım. Yalnız teknik unsurları kullanan bir mantıktaki merhametsiz ofomafizmin bizi ne gibi manâsızlıklara sevkedebileceği hakkında bir fikir verebilmek için bunları hatılatmak kâfidir.

Çok zamanlar teknisiyenler onlara yanlıs yolda yürüdüklerini haber vermekte gecikmiyen pratik hayatın mukavemetleri sayesinde bu otomatizmin suiistimallerine karșı ihtiyatlı bulunurlar. Fakat her zaman vaziyef böyle olmaz buna tüzel kıșılık yani insandan gayri realitelere isnad edilen hukukî kişilik mefhumunun garip taliinden başka delil göstermek istemiyorum.

Hatta kullandığım formül bile size, hükmî şahsiyet ile hukukî şahsiyeł arasında Hauriu'nun tavsiye ettiği tefriki yapmağı kabul efmediğimi gösterir. Konfransımın ikinci bölümünü trhsis ettiğim tüzel kişilik mefhumu, fikrimce, hukukî mefhumculuk ile hukukî gerçekçiliğin hakiki çatışma sahalarıdır.

Baștan da size söylediğim gibi, șimdi de buraya kadar serd ettiğim mülâhazalardan sonra șunu tekrar edebilirimki Duguit sübjektif hakka karșı yaptı̆ı garip ve beyhude tecavüzü ile bu ihtilâfı büsbütün karıștımıs olmasa idi bu hususta son sözü onun söylemiş olması lazımgelirdi. Emin olunuz ergeç bizim hukuk tekniğimizi hükmi şahsiyet mefhumundan kurtarmak suretile sarf ettiği müessir gayretten dolayi kendỉine müteșekkir kalınacaktır. Bu meselenin daha pek çok mürekkep sarf ettireceğini itiraf etmiyor değilim. Zira kötü itiyadlar, kendilerinden kolaylıkla kurtulunabilen şeyler değildir.

Süphesiz ki cemiyetler gibi topluluklara veya tesisler gibi kurumlara affedilen bu tüzel kişilik kavramı, bir haktan edilecek istifadenin büyük sayıda veya miktarı gayri muayyen olan bir müstefidler kitlesi üzerinde dağılıp gitmesi halinde bütün bu ferdi istifadeleri bir demet halinde toplamak ve onlara bir tek sahip yaratmak ihtiyacından doğmuștur. Bu ihtiyacı izah için Duguit'nin zan ettiği gibi, hukukcularda halâ yaşamakta devam eden ve onları «lçtmaî surette himaye edilmiş her faaliyetin arkasına bu himayeyi izah için mẹtafizik esastar yerleștirmeye» sevk eden bir dinî zihniyete atıf yapmak gerektiğine inanmiyorum. (Dr. Cons. I. Sh. 178) 
Her șeyden evvel bu cemiyet veya tesis tarafindan temsil edilen menfaatlar yekününü tek bir kelime ile ifade etmenin lisan bakımından olan elverişliği yüzünden böyle bir mefhum icad edilmiş olduğuna hüküm etmeh çok daha tabiidir. Sonra bu kelimenin arkasında hakikaten şahıslandırılmağa müsait bir gerçeklik bulunup bulunmadığını sorușturmak da bundan daha az tabii değildir. Bu suallere bazıları hayır dediler. Fakat biz sanki bu șahıslandırılmağa müsait gerçeklik mevcutmuş gibi harehet edeceğiz. Bu fikri kabul eden ister kanun koyan, ister kanunu tefsir eden makam olsun, yani bu, ister kanun ister ictihada dayanan bir fiction olsun, biz daima mesnedini gerçeklikten almayan bir teknik icadi karşısında bulunuyoruz demektir. Bu andan itibaren ortada bir şahsiyet mevcutmus gibi davranılır. Zira hakikatte mevcut olmadığı bilinmektedir. Iște bu mefhumculuktur.

Diğerleri: evet dediler. Süphesizki size, tüzel kişilik gerçekliğini isbat etmek ve böylece mefhumculuk ittihamından kurtulmak için yapılmış olan bu denemeleri toplu bir halde arz etmemden memnun kalacaksınız. Bazileri cemiyetlerin uzviyetci telekkisine iștirâk ettiler ki bunlar cemiyetlere bir cinsiyet tanımağa bile kalktılar. Digerleri ise cemiyette birleșmiş olanların veya cemiyetin faaliyetinden müstefid olanların ruh ve iradelerinden ayrı bir kolllektif ruh, bir kollektif irade mevcut olduğunu iddia ettiler. Iddia ettiler diyorum, çünkü bunu hiç bir zaman isabet edemediler .- Bu telakkinin en oriiinal ve en yeni müdafaası Hauriou tarafindan yapılmıștır ki ona göre «\$̧ahıslandırma iki perdeden ibarettir: Birinci perde : objektif bir ferdiyetin teşkili (cemiyet veya tesisin kurulması). Uzuvları olan bir sosyal otomat ve müvazeneli bir iç idare. Fakat bu henüz sübjektif Alevden mahrumdur. Çünkü tarihi bakımdan daha evvel teşekkül eden vücuttur. Ikinci perde : sübjektif cevherin yaratılması ve tezahürü «(Principes de Droit public. 2 éd. 1916 sh: 41 ). Bu sübjektif alev nedir? Bu «gurup üyelerinin müsterek iradesinde ayni zamanda hem bir manevi hak sahibi hem de bir mal iktisap etme kabiliyeti şeklinde tezahür etmek isteyen içtimai eser fikridir.» (Ayni eser Sh, 107.n.l) Peki bu alevi kim tutuşturạcak bașka tabirle, hangi anda ikinci perde açılacak?» Bu, «organların gurup üyeleri karşısındaki manevi mesuliyetleri» olayının baş gösterdiği anda vaki olacaktır. (Principes de Droit Constitutionnel 1923 Sh: 716. 2. ek). Bu mesuliyet hissi şiddetlendikce hükmi şahsiyet inkişaf eder, gelişir. «Duguit bu gibi mefhumlar münakașe edilmez diyor. Bunlar sadece zihnin yaptığı hayallerden ibarettir." (Droit Constitutionnel I, Sh: 353). Nazariyeye karșı böyle bir reddin pek muhtasar olacağını biliyorum. Faka: beğenmekie de tereddüt etmiyorum. Ben, kollektif irade, içtimaî vicdan gibi mefhumlari hukukcuların asla kabul efmemeleri gereken :htiyatsızca yapılmıs istiarelerden ibaret telakki edenlerdenim. Bir insan ze- 
kâsına raptedilemeyen, müşahadesi kabil hiç bir cevhere izafe edilemeyen tecerrüd halinde bir irade veya vicdan tasavvuru benim için imkânsızdır. Bu tam manasile bir hilkat ucubeliği, bir tabiat galatlığıdır. Bütün kollektif veya sosyal vakıalar esas itibarile ferdî vakıalara irca edilebilirler ve bunların dışında ayrı bir varlık teșkil etmezler. Cemiyet içinde yaşayan, müșterek bir hareket etrafında toplanan veya sadece bir kalabalık halinde bulunan ferdlerin ruhlarında iradelerinde ve vicdanlarında; onları, artik yalniz oldukları zamanlardaki gibi düșündürtmeyen, istełmiyen veya hareket ettirtmeyen bir tesir ve aksi tesirler, bir etki ve tepkiler serisi olabilir, bu husus münakaşadan hariçtir. Hatta Psychisme social veya Psycholagie social adı altında bu tesirlerin karmașiklığı veya bu tesir ve aksi tesir münavebeleri tetkik edilebilir, mümkün; fakat bu sosyal Psychisme'leri bilmem hangi kollektif ruha affełmek temayülüne kapulınmamalidir. Sosyal Pshchisme ler ancak birbirlerile temas haline getirilmiş olan ferdî Psychisme'lerin evsaf ve hususiyetlerinden yaratılır. Muşahadesi kabil gerçeklikler yalnız bu evsaf ve hususiyetlerdir. Kollektif irade ve kollektif vicdan gibi istiarelerin alłında șimdi zikrettğiimiz gerçekliklerden bașka hiç bir șey yoktur ve olmayacaktır.

Bu muhakeme, hangi şekil altında olursa olsun, tüzel kişiliğin gerçekliğini kabul eden doktrinlere olduğu kadar, Hauriou'nun dâhiyane inşa ve icadlerine ve bazi Alman hukukcularının buiutlu, mübhem veya pek basitleștirici formüllerine de muhaliftir. Bununla beraber Hauriou'nun görüsünde, bir mesuliyet hissinin nasıl olup da henüz varlık kazanmamıș, bir şahsiyete takaddüm ederek onun doğumunu intac edebileceğini anlamanın bana pek güc geldiğini de ilâve edeyim. Zira bu hissin, bir sahsiyetin varlığını duyması ve böylece onun mıhrakını teșkil edebilmesi için her halde o şahsiyetin kendisinden daha evvel doğmus yani bir varlık kazanm $\$$ olması lâzımdır.

Cevheri arazdan cıkartmağa müncer olan bir sistemin gerçeklikte mesnedi yoktur. Bu sirf bir muhayyele eseridir.

Fakat tüzel kişiliklerin gerçekliği meselesi, mevzuu temamen başka sahaya nakleden diğer müdafiler de buldu. Bunlar; "ne olduğu anlașılmayan bir maşeri irade veya vicdan mefhumu peșinde koşmakta niçin bukadar israr ediliyor?» cediler: Bu hareket noktası fenadir. Bu noktadan hareket edildiği zaman irade sübjektif hukukun temeline yerleștirilmiş ve bunun neticesinde de, herkesin fikrine aykırı olarak, sübiektif hakların sahibi sıfatiyle hükmişahsiyetlere de bir irade izafesi icab etmiştir. Halbuki biz sübjektif hakkın temeline irade yerine bu iradenin himaye ve müdafaa ettiği asıl menfaati 
koyacak olursak bütün güçük ortadan kaikar. Sahsiyet artık irade kullanmak kabiliyeti değil, belki istifade kabiliyeti demek olur. Bir topluluk, bir cemiyef hukukan himaye gören bazı menfaatlara sahip olur olmaz hükmișahsiyet halini alabilir. Iște Léon Michoud'nun hükmî şahsiyet nazariyesi budur. Görüyorsunuz ki bu nazoriye bizi sübjektif hukukun temeli meselesinde bir cephe almağa sevk ediyor. Bu bakımdan hükmişahsiyet meselesinin bütün hukuk felsefesine hakim telakki edilmesi yerindedir.

Bu saha değiştirilmesinin hükmişchsısların gerçekliği davasına bir fayda temin etmiş olduğunu zan efmiyorum. Filhakika Michoud'nun nazariyesi iki postulat üzerinde dayanmaktadır ki bunların her ikisi de söz götürür cinstendir.

Birincisi, ferdi menfaatlara ircaı kabil olmayan topluluk menfaatlerinin mévcudiyeti meselesidir. Bir cemiyetin, bir resisin menfeati, hiçbir zaman bir ferdi menfeatler mecmuundan başka birșey değildir. Bu ferdi menfeatlerin daima, yașayan ve bilinebilen ferdlerin menfeati demek olmadığını iyice anlamalısınız. Bunlar belki topluluk azası olmayan hattâ bazan henüz doğmamiş olan ferdlerin menfeatleri olabilir. Fakat daima ferdi menfeatlar olarak kalir.

Umumi, kollektif veya Korporatif menfaat denen șeyler haddizatinde daha çok sayidaki ferdi menfeatler yekûnünden ibarettir ki bazen bunlar hususî menfeatler denen az soyıdaki ferdî menfectlara aykırı düserler.

Íkinci postulat ise sübjektif hukukun temeline müraallıtır. Bu, gerek Fransa'da ve gerek yabancı memleketlerde, uzun bir zaman ve burada red ve cerhini faydasız kılacak kadar münakașa ve itirazı mucip olmuștur. Ben bu hususta ancak cari lisandan; yani prensip itibarile hukukcuların kullanmaları gèreken yegâne lisandan çkma bir tek delil göstereceğim: Ferdi hak mefhumunun ilk akla getirdiği fikir hangisidir? Menfaat fikri mi yoksa irade kudreti fikri mi (benim falan hakkım var) gibi en basit bir sözü duyduğumuz zaman bu yarım kalmıs cümle acaba aklımıza bir menfaat fikrini mi getiriyor?

Muhakkak ki hayır.

(Benim falan hakkım var) cümlesi herseyden evvel, benim bir talep selahiyetim var, birșey istemek selahyetim var, bir irade beyani ile içtimai cébri harekete getirmek imkânım var fikrini ifade ediyor. (Neden dolayı?) (Hangi gayeye erișmek için?) sucli ancak bu fikirden sonra akla gelecektir. Iste menfaat, ancak bu anda, yani ikinci safhada bahis mevzuu olacaktır. Hukukculara, kendi nazariyelerine uydurmak için kelimelerin mutad manalarını değiștirmek selahiyefi verilemez. 
Demek ki eğer sübjektif hukuk esas itibarile bir iradenin emrine veriimiş bir cebir selâhiyeti ise, bu, ancak bir insanın, yani müşahadesi kabil gerçeklikler içinde bir zekâ ve irade ile mücehhez olan yegâne mahlukun vasfı olabilir. Demek ki ancak insana bir hukukî şahsiyet yani bu hakkı istimal selahiyeti verilebilir neticesine varryoruz.

Ben hümișahısların gerçekliği fikrinin kal'î bir muarızıyım.

Fakat beni iyi anlayınız.

Ben bununla hükmişahsın büsbütün mesnedsiz oiduğunu, boşluk üzerine kurulduğunu söylemek istemiyorum. Aslâ. Bu cemiyetler, bu tesisler, bir kelime ile hümişahsiyet ile techiz edilen bütün bu teşekkülier hiç șüphesiz müşahedesi kabil gerçekliklere istinad eden hukukî realitelerdir. İște bir gayeye tahsis edilmis bir mal kitlesi. Iște bu gayeyi tahakkuk ettirmek için müsterek bir gayret sarf edenlerin faaliyetleri ve bu faaliyetler arasında bir hiyeraşi, bir iș bölümü, hülâsa, işleyiș tarzı tanzim edilmiş ve muayyen bir gayeye tahsis edilmek üzere kurulmuş bütün bir mekanizma.

Bir kerre daha söyliyeyim ki bütün bunlar bir gerçekliktir. Fakat ben bu gerçekliğin bir șahıs olduğunu kabul etmem. Hauriou nun tabirini kullanarak diyelim ki, ben, bu teşekküllerin (objektif ferdiyetini) kabul ediyorum. Bu objektif ferdiyet müșahedesi kabil realiteler gurubundandır. Fakat bu objektif realiteden "sübiektif şahsiyete» olan geçii bizi kelimenin kötü manasile tam bir mefhumculuğa götürür.

Ben bu teşekküllere sahsiyet izafesinin arcak bir fiction sayesinde tiumkün olacağına kani olmakta berdevamim. Fiksiyonșahsiyet hakkındaki eski nazariye kendisire dayanılabilecek yegâne nazariyedir, hiç değilse bu bakımdan böyledir. Zira yine geriye bu fiksiyonun faydalı olup olmadığını bilmek meselesi kalıyor. Ben buna da kani değilim.

Halbuki, bir fiskiyon faydasız olunca tehlikeli de olur.

Size burada fiksiyon - șahsiyet nazariyesinin bir tenkidini yapacak değilim. Artık bunun zamanı geçmiștir.

Bunu Léon Michoud nun büyük eserinde makul ve ölçülü bir șekilde bulacaksınız. Vareilles - Sommière'in hükmișahısiara tahsis ettiği kitabında da canlı ve nükteli bir şekilde bulursun'z. Görülüyorki ben, hükmişahısların varlığını, Devletin keyfine teslim etmè̉ tehlikesi üzerinde durmuyorum. Yani bunların varlığını kabul eder görünmeye razı olup olmaması bakımından olan tehlike. Keza, henüz daha bir varlik kazanmadan bizzat kendisine fiksiyon asıtasile bir mevcudiyet bahș edemiyeceği cihetle, fiksiyonsuzca bi- 
zatihi var olması gereken yegâne hükmişahıs olan devletin sahsiyetini mevzu dısı bırakmanın mantıksızlığını da gösterecek değilim. Ben yalnız sizin dikkatinizi alelitlak bütün fiksiyonların ve bilhassa faydasız fiksiyonların en vahim mahzuru üzerine çekmekle iktifa edeceğim.

Mevcul olmayan her hangi birşeyi mevcutmus gibi kabul etmek, zamanunda durulması bilinmemek tehlikesi olan bir yola koyulmak demektir. Eğer fiksiyon hakikaten faydalı ise hakikaten pratik zaruretler tarafından kabul ettirilmiş ise, belki onu bu zarureterin hudutlan içinde hapsetmek daha az güç olur.

Fakat faydalı değilse, daha fazla hayal sahasina dalmamak için hangi anda fren yapılacaktır?

Fiksiyonun büyük tehlikesi, şudur ki, ergeç bu fiksiyon gerçeklik haline inkilap ettirilmek istenir.

Fiksiyon - șahsiyet nazariyesi zihinleri hükmișahsiyetlerin gerçekliğini kabule hazırlamış̧ı. Bizde daima iptidaî insanın tabiat kuvvetlerini ilâhlaştırmak temayülü bakîdir. Bu temayül bizi bu gün zaman mekân bạkımından kendi küçük ferdi faaliyetimize konmuş olan hudutları aşan kollektif kuvvetleri şahıslandırmağa sevk ediyor. Böyle bir kuvvetin bizim takatımızı așması vakıası karşısında, ilk hareketimiz, ona derhal kendi sahsiyetimizden daha büyük çapła bir şahsiyet izafe etmek oluyor. Hale göre bu şahsiyete millet, Devlet, veya idare, kumpanya diyoruz veya diğer adlar takıyoruz. Fakat öyle görünüyorki o, bizim için ne kadar uzak, ne kadar belirsiz, ne kadar anlaşılmaz bir halde ise ona okadar geniş haklar tanıyoruz. Bu gün hukukcular dünyasında hayli itibarden düșü̧s ve fakat kitle indinde daima hos tutulmus olan millî egemenlik efsanesi de iște bu sekilde vücut bulmustur. Ne çok insan millî egemenlikten bahşeder de, kendisini teşkil eden ferdlerin dışında milletin ne demek olacağını düşünmez! Millet; içimizde âmme hukukunu tetkik etmiș olanların bildiği gibi, tarifi müşkül bir takım mefhumî unsurlar mecmuasından başka nedir? Bu itibarla milletin kendine ait ne zekâsı ne iradesi vardır. Bununla beraber en ulvî hak, egemenlik gibi bir hak iște bu sarahattan mahrum mefhumlar mecmuasına izafe edilmektedir. Coğunluk diktatörlüğü ve egemen milletin irade beyani addedilen seçim oyunu sayesinde sayıya esir olmak gibi haller iște bu fiksiyonun neticeleridir. Mantıkî istidlâller zincirinin ucu bir kerre bir fiksiyona rapt edildimi, artık herşey beklenebilir. Milleti deviette, yani bir bașka hükmişahısta sahıslandırmak suretile işin içinden çıkılacağını mı zan ediyorsunuz? Ohalde kıralın (devlet: benim) dediği zamanlara dönmemiz lâzım. Devlet bir insan olunca 
hak süjesi de olabilirdi. Devleti ancak bir hükmî șahıs haline irca ettikten sonra ana egemenlik bahșetmek, milli egemenlik methumundan hiç bir cihetle üstün olmayan, ayni neviden başka bir mefhuma itibar göstermek demektir. Bu yeni mefhumun ömrü de evvelkinden daha uzun olacak değitdir. Bu Devlet hükmî şahsieyti hakkında, en kıymetii hukukçulai arasında bile ne kadar fikir ayrılığı vardır; bazıları tek bir sahsiyet kabul eder, diğgerleri bu şahsiyeti ikileştirirler nihayet bir kısmı da ancak mamelekî şahsiyeti kabul etmek için ve daha bazı elverişlilik sebepleri yüzünden iktidar sahsiyetini reddeder.

Bu mefthumun bir engel teșkil ettiğine ve kendisinden kurtulunmak istendiğine bundan daha iyi delil mi olur? İarecilerin sanıslarınm dışında bir devlet olmadığı ve devlet rejimi denen şeyin idare edenlerie idare edilenlerin birbirlerinden basit bir farklılașmaiarı neticesinde kurulduğunu keșfetmek için bu kadar gayrete lüzum var mı?

Hümişahsiyetin herșeyi insana benzeterek düșünme temayülünün muayyen bir sathası olduğunu itiraf ełmek için samimî olmamız lâzımdır. Pek yákın zamaniarda hükmişahsiyetierin hakiki bir cezai mesuliyetle ilzam edilebileceklerini isbat için yapılmıs olan teşebbüslere başka ne mana verlir?

Bu gibi teşebbüslere ahılan kimselerin bununla, içinde ne zekâ ne de irade bulunan birşey üzerinde cezai bir tenkil usulü tesis ederek ceza hukuku prensiplerini alt üst ełmek istemiș olacaklarmn da zanetmiyorum. Bu kimseler şayet cezai mesuliyetin kendi ananevî unsurlarını muhafaza edeceğini kabul ediyorlarsa, bu hareketlerile tecziyesi kabil addettikleri hükmișahıslara bir zekâ ve bir irade izafe ediyorlar demektir. $8 u$ ya herseyi insana benzerme temayüldür yahut da ceza hukukunun alt üst edilmesi. Uçüncü bir ihtimal yoktur.

Bu arada bunlarm cezai müesseselerimize bazı yenilikier sokmak için yapıldığ! iddiasın! da hatılatalım. Halbuki pek âlâ bu yeniliker bu gibi dolambacli yollara sapilmadan da yapllabilirdi.

Simdiye kadar iste: fiksiyon olsun, ister bir sözde realité olsun, hükmişahsiyet telâkikinin tehlikeleri üzerinde ssrarla durdum. Artk bunun yahnz bizim bu günkü hukuk tekniğimiz için değil, belki yeni unsurlarla islah edilmiş ve zenginleştirilmiş başka bir hukuk tekniği için de faydasız olduğunu isbat efmenin zamanı geimiștir. Ne zaman hükmişahsiyet mefhumunun kabulünü icap ettien münhasıran hukukî neviden mülâhazalan hatırlasam, içlerinden belli başlı iki mülâhaza üzerinde dururum : 
1 : Bu telâkkinin muvaffakiyeli evvelâ 'ukukan sahipsiz mallar olamayacağı yolundaki kablî kanaat yüzündendir. Bir tesise tahsis edilmiş mollar, bir cemiyette toplanmıs mallar müessislerin veya cemiyet üyelerinin mülkü olmaktan çıkıordu. Onların hiç kimseye aif olmamclan ihtimaii ise imkânsız ad ediliyordu. O halde herçebâdabâd onlara bir sahip bulmak icap ediyordu $k i$ bu sahip de sahıslandırılmış olan tesis veya cemiyet oluyordu. Cemiyeł veya esisin yokluğu halinde bu mahlôl ve sahipsiz mallar devlete izafe ediliyordu. Yani yine bir bașka hükmişahsa. Fransada uzun zamanlardanberi hukukî tefekkür böyle münkașcisızca kabul edilmiș bir kab!i kanaatin hakimiyeti altında’kaldı.

Bununla beraber sahipsiz olan ye fakat muayyen bir gayeye tahsis edilmis bulunan mallar mefhumunda akia uygun gelmeyen bir şey yokłu. 1908 de Saleilles hükmişahsiyet hakkındaki dokłora derslerini verirken dinleyicilerin dikkatini Brinz'in nazariyesine çekmişti. Saleilles (tahsis mameleki - Zweckvermögen) nazariyesinin muvakkat bir hayranlığı davet ettikton sonra, müstahak olmadığı bir itibarsızlığa düşmüs olmasına teessüf ediyor: du. Kendisi bu nazariyeye iștirak etmiyordu. Fakat onu akla mugayir olmakla ittiham etmek şöyle dursun, bilâkis hukukî fikirlerin terakki yolundaki mühim bir merhalesi olarak gösteriyordı.

Ben kendisinden dahe ileri gidiyorum ve bu üzerlerinde mülkiyet tesis edilmemiç ve fakat bir gayeye rahsis edilmiş olan mallar methumunun, müsahedesi kabil bir gercekliğe dayandiğm kabul ediyorum. Bu mefhum bize amelî hayat tarafindan telkin edimiģtir ve bizim hukuk tekniğimizin ona lâyık olduğu yeri verecek yerde, onun vasıtasızca varacağı neticeye erișmek için bukadar zamon uydurma bir vasila kullanmıs olması cidden hayrete değer.

Iște, bir șehirde büyïk harpte ölenlerin hatırasına bir âbide dikilmesi için kurulmus bir heyet tasavvur edin. Bu heyetin hükmişahsiyeti yoktur. Fakat aidati toplayan bir veznedar! vardir. Yatırlan para muhakkakki yahranIarın mülkü oimaktan çıkmıstır. Fakat bununla hukuk süjesi saylamıyan heyefin mülkiyetine de geçmiş değildir. Keza veznedarn mülkiyetine de geçtiği iddia edilemez. Nihayet bunlarin deviete izafesi de tecviz edilemiyecektir.

Suhalde iște bu günkü tekniğimiz içinde hukukî hali olmayan paralar. Halbuki biz sahsis mamelekini kabul edersek bu paralar bir hukukî hale sahip olacaklardir. Demek ki hukukan sahipsiz mallar ile sahipli mallar arasinda orta bir hal kabul etmeye karar vermeliyiz. Bu orta hal, bir gayeye tahsis edilmiș ve binnetice üzerierinde ancak bu gayeye erișmek için tasarruf edilebilen mallar mefhumudur. 
Hümişahsiyetin hikmeti vücutlarından biri böylece ortadan kalkacaktır. Artık tesis veya cemiyet mallarının mülkiyeti kendisine izafe edilebilmek için șahıslandırılması gereken bir kollektif varlık araștırılması beyhudedir. Bundan sonra bu malların mülkiyet mevzuu haline sokulmalarına hacet kalmadan içine yerleștirilebilecekleri bir hukukî kałegori mevcuttur: Tahsis mameleki kategorisi. Iște doldurulması gereken bir boșluk ve tashihi gereken bir hata.

2 : Ikinci sebep : - daima münhasıran hukukî neviden - hükmișahsiyet mefhumunun tutunmasın temin eden diğer sebep de șimdiye kadar bir sübjektif hakkın sahibi olarak ancak ondan istifade eden kimsenin tanınmasında ısrar edilmesi idi. Yani hakkın sahibi olarak, onu tahrik edebilen, bașka tabirle istimal eden kimse değil de ancak ondan müstefid olan kimse tanınıyordu. Bu itibarla ne zaman bir haktan edilecek istifade gayri muayyen bir ferdler kitlesi üzerine dağılsa, derhal bu kitleyi șahıslandırmak fikrine sapılıyordu. Hattô böylelikle kitle daha mübhem, daha tayini imkânsız bir hal aldığı halde dahi sübjektif hakkın iptidai unsuru gibi telâkki edilen menfact unsurunu bu șahsa rapt edebiimek için yine bu tarzda hareket edilmiş oiması gariptir. Iște sübjektif hakkın sahibi olarak, iradesile onu harekete getirebilen kimsenin kabulü hususunda bir anlașma vaki olduğu günde hükmişahsın; artık kıymeti kalmayacak olan bir faydası daha!

Size kendi fikirlerimi daha iyi anlatabilmek için, her sübjektif hakta iki unsurun tefrik edildiğini ve bunun da hükmisşahsın müștereken kabul edilmiş olan tarifi yüzünden yapıldığını hatıllałmama lüzum var mı? Hak, hukukan himayesi gerektiăine hüküm olunan bir menfaatin mijdafaası için bir iradenin emrine verilmiş bir zecir selâhiyetidir.

Menfaat unsuru ile irade unsuru çok defa ayni elde birlesir. Bazen bunlar birbirlerinden çözülürler ki bu, ehliyetsiz ile onun kanunî mümessilinin halidir. Nihayet bazan menfaatlerin tecezzisi okadar fazlaár ki müsiefidler tayin edilemez bir hale gelir. Meselâ alpliler kulübünü (Touring-club) veya Souvenirs Français gibi askeri mezarlara bakma cemiyetini alalm: bu kakdirde bütün bu ilgilileri, içinde sayısız meçhuller bulunan bir adedi gösteren bir nevi cebir işareti altında toplamak için hükmişahsiyet mefhumu elzem gibi görünür.

Bir hakkın sahibi olarak, ondan istifade eden kimseyi değilde, içtimai cebri harekete geçirebilmek selâhiyetine sahip olan kimseyi kabul edersek mesele nekadar basitleșir. Bunda yeni birşey var mı? 
Muhakkakki hayır, ve aşağıdaki mülâhazaların yardımı ile bunu size isbat bence kolaydir. :

Birinci mülâhaza: Leon Michoud nun nazariyesi aleyhine en kat'î itiraz hangisi idi? Bu, Ferrara'nın ithamı vechile sübjektif hakkı, menfaat ve irade gibi iki esaslı unsurdan mürekkep olarak gösterdikten sonra iradenin hak sahibinden gayri bir kimsede bulunabileceğine ihtimal vermesi hususu idi. Eğer bu tenkid haklı ise ve eğer bu konferansın başında size isbat ettiğimi zan ettiğim gibi sübjektif hak herşeyden evvel bir talep kudreti ise, ne zaman bu iki unsur birbirinden çözülse, irade unsurunu temsil eden tarafı, hakkın yegâne sahibi olarak telâkki etmek icap etmez mi?

Ikinci mülâhaza : Bu bana cari hukuk dili tarafindan telkin edilmiştir. Hergün, savcının dava hakkından bahis edilmiyormu? Halbuki buradaki menfaat unsuru, savcının müdaafası ile mükellef olduğu cemiyetin azaları olmak sifatile bizler üzerinde dağıldığından, onun, ancak irade unsurunu temsil ettiği şüphe göłürmez.

Kendi uhdesindeki hakların istimalinden doğacak menfaattan bizzat kendisi faydalanmadığı halde, vasinin haklarından bahis edilmiyor mu? (7)

Uçüncü mülâhaza : Sendika davaları sahasinda gelişen içtihad ve teșri tekâmülü bizi, hak sahipliği vasfını, irade unsurunu elinde bulunduran tarafa tevcihe sevk ediyor. Bu tekâmülün, kendilerine, herșeyi insana benzeterek düșünme temayülü yüzünden bir irade tanınmıs olan bir takım hükmişahıslar lehine meydana geldiğini müşahade etmek acı değil midir? Halbuki bu hükmișahıslara atfedilen irade, hakikatta bunların idarecilerinin iradelerinden ibarettir.

1913 de Yargıtay umumi heyeti, muhakemesi yapılmakta olan suç sendika için hiçbir hususi zararı müeddi olmayıp sadece aielılak mesleki menfaatleri haleldar etmekte olduğu halde sendikaların tazminat (hukuk) davası açabileceklerini kabul etti. (8)

10 Temmuz 1915 kanununa göre, elbise sanayiinde çalışan ev işçilerinin asgarî gündeliklerinin korunmasına mütaallik hükümlerin ihlali halinde, sendika, kendisine her hangi bił zarar iras edildiğini isbate muhtaç olmaksızın dava açabilecektir. (Art, 33-K Code trav. Lt)

(7) - Görüldüğü gibi ben vazife ile hakkı birbirlerile tearuz eden mefhumlar ola. rak kabul etmem. Sübiektif hakkın temel olarak, menfaat unsurunu değil de, irade un. surunu kabul eder etmez bu taaruzun manası kalmaz.

(8) - Cass, Ch, 5 avril 1913, D. P 1914, 1.65 
1920 de 12 Mart hanunu bu usulü teyid eder ve onu mesieki müdafaa maksadile açlacak bütün sendika davalanna teșmil eder.

Iște, açikian açığa bir vazife hizmetindeki irade unsuruna dayanan hak. Hakikalta ise bu irade sendika hükmüșahsinin olmayıp, beiki tamamen sendika idaresine ve onun faaliyetine mütedair Tüzüklerle tayin edilen üyenin veya üyelerinin iradesi olduğundan, hak sahipliği vasfinın kanun ve içtihad tarafından her hangi bir hakkın istimalinden şahsen müstefid olmadikları halde bir irade harekeyi ile içtimai cebri harekete geçirebilen kimselere tanındığı neticesine varılmazmı?

Benim teklif ettiğim şey, hak sahibi olarak gâh hakkı kullananı, gâh ondan faydalananı kabul eden bugünkü tekniğimizçeki irtibatsızlığa bir nihayet vermekłedir.

Artık kat'î olarak irade unsurunun üstünlüğünü kabul edelim. Böyieco artık mevzuu kalmamıs olan hükmişahsiyeì mefhumundan kendimizi kurtaralım. Zira artık ne bir sahibe ihtiyac kalmayan tahsis mamelekinin mülkiyeitini izafe için, nede bir sübjektif hakkın gayri muayyen müstefidlerini iemsil için ana ihtiyacımız olacaktır. Burada anlattığım iki meíhum, hükmişahsiyetin yerine, gerçekliğe dayarian ve tamamen ayni olmamakla beraber ingiliz hukukundaki Trust'e yakınlașan bir hukukî inșanın (Construction) ika. mesine imkân verecektir.

Tekniğimizin bu istihaiesi, hukukî realizmin büyük bir zơferina cilômei olacaktı. 